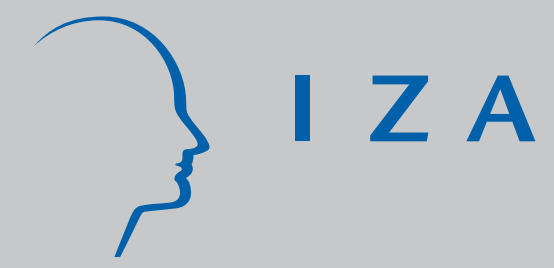

IZA DP No. 1415

Recent Developments in Part-Time Work in EU-15 Countries: Trends and Policy

Hielke Buddelmeyer

Gilles Mourre

Melanie Ward

November 2004 


\title{
Recent Developments in Part-Time Work in EU-15 Countries: Trends and Policy
}

\author{
Hielke Buddelmeyer \\ Melbourne Institute of Applied Economic and Social Research \\ and IZA Bonn \\ Gilles Mourre \\ ECFIN, European Commission
}

Melanie Ward

European Central Bank, CEPR and IZA Bonn

Discussion Paper No. 1415

November 2004

\author{
IZA \\ P.O. Box 7240 \\ 53072 Bonn \\ Germany \\ Phone: $+49-228-3894-0$ \\ Fax: +49-228-3894-180 \\ Email: iza@iza.org
}

\begin{abstract}
Any opinions expressed here are those of the author(s) and not those of the institute. Research disseminated by IZA may include views on policy, but the institute itself takes no institutional policy positions.

The Institute for the Study of Labor (IZA) in Bonn is a local and virtual international research center and a place of communication between science, politics and business. IZA is an independent nonprofit company supported by Deutsche Post World Net. The center is associated with the University of Bonn and offers a stimulating research environment through its research networks, research support, and visitors and doctoral programs. IZA engages in (i) original and internationally competitive research in all fields of labor economics, (ii) development of policy concepts, and (iii) dissemination of research results and concepts to the interested public.
\end{abstract}

IZA Discussion Papers often represent preliminary work and are circulated to encourage discussion. Citation of such a paper should account for its provisional character. A revised version may be available directly from the author. 


\title{
ABSTRACT
}

\section{Recent Developments in Part-Time Work in EU-15 Countries: Trends and Policy*}

\begin{abstract}
A growing part-time employment share has been a main feature of a number of industrialized countries over the past two decades. A considerable variation in the rate of part-time work is evident by gender, age group, industrial sector and occupation. The stylized facts support the view that part-time employment represents an important opportunity particularly for young, older and female workers to enter the labour markets of the European Union. For the majority of workers in these groups, the decision to work part-time has been a voluntary one, which is all the more satisfactory in terms of welfare maximization.

Our results indicate that the development of the part-time employment rate over time and the strong variation in the PTR across countries are significantly affected by policy and institutions. In particular policy measures geared toward encouraging part-time work are found to be positively related to actual part-time developments. These measures include both the legal framework directly affecting part-time positions and the creation of financial incentives (subsidies and improvement of social protection) to take up a part-time job. Moreover, other labour market institutions, including benefit systems and the stringency of employment protection legislation for regular contracts, are found to significantly but indirectly influence the growth in part-time work.
\end{abstract}

JEL Classification: J21, J22, J28

Keywords: part-time employment, labour supply, labour market policies, institutions, regulations, subsidies

Corresponding author:

Hielke Buddelmeyer

Melbourne Institute of Applied Economic and Social Research

Melbourne University

Alan Gilbert Building, $7^{\text {th }} \mathrm{FI}$.

Parkville, VIC 3010

Australia

Email: hielkeb@unimelb.edu.au

\footnotetext{
${ }^{*}$ The views expressed in this paper are those of the authors and do not necessarily reflect those of IZA, the European Commission or the European Central Bank (ECB). Gilles Mourre was working at the ECB whilst a preliminary version of this paper was written. We would like to thank Nadine LeinerKillinger (ECB) who compiled some information on part-time policies.
} 


\section{Table of contents}

1. Introduction $\quad 5$

2. The determinants of part-time work - A survey of the literature 6

3. Trends in part-time work in EU countries $\quad 7$

4. Regulations towards part-time work in EU countries 10

5. The effect of regulations and labour market institutions on part-time employment 12

5.1 Data and estimation strategy $\quad 12$

5.2 Results 14

6. Policy conclusions 16

$\begin{array}{ll}\text { References } & 18\end{array}$

$\begin{array}{ll}\text { Figures and Tables } & 21\end{array}$ 


\section{Introduction}

Over the last 20 years, Europe has experienced a dramatic increase in the share of part-time employment. This increase is generally regarded as a positive trend, since the promotion of parttime work may be an important measure through which the flexibility of labour markets can be increased. On the labour supply side, part-time work may increase the labour market choices open to individuals, drawing people into the labour market that were previously unwilling or unable to work. On the labour demand side, it may allow employers to adjust hours worked to fluctuations in demand more easily, facilitating adjustment of production and labour costs. The functioning of euro area labour markets and their ability to adjust flexibly to adverse economic shocks are crucial for the single monetary policy. Helping inactive or unemployed persons to (re-)enter the labour market also increases potential output in the European Union. Furthermore, the increase in part time positions represents positive progress in achieving the employment targets of raising the EU employment rate to 70 per cent by 2010 and of increasing the female employment rate to more than 60 per cent by $2010^{1}$, set up by the Lisbon European Council in March 2000.

However, it is crucial to know more about the characteristics of this increase in the parttime employment share, such as which groups of the labour force are most likely to work part time and which jobs are most likely to be offered as part-time positions. Also important is to what extent part-time jobs offer career development opportunities. Furthermore, despite the generally positive trend in the incidence of part-time work, there are still remarkable differences in the relative sizes of the part-time employment share by country within the European Union ${ }^{2}$. This suggests that policy, institutions and/or preferences toward part-time work are very different across different regions of the EU.

In recent decades, policies promoting flexible working arrangements have been implemented in several EU countries (OECD, 1998). Against this background, the objective of this paper is to outline some stylized facts concerning the key characteristics of part-time employment in EU countries as well as the impact of policy and institutions. Section 2 briefly reviews existing literature on part-time work and its determinants. Section 3 outlines the key differences in the incidence of part-time work and its development over time for each of the EU

\footnotetext{
${ }^{1}$ The Stockholm Council set intermediate targets for 2005 of 67 per cent for the total employment rate and 57 per cent for female employment and an additional target to increase the EU employment rate for older women and men (aged 55-64) to 50 per cent by 2010. These objectives are meant to contribute to making the EU 'the most dynamic knowledge based economy in the world, capable of sustainable economic growth with more and better jobs and greater social cohesion'.

${ }^{2}$ Here the EU refers to the EU-15; we therefore consider the EU prior to its enlargement to 25 Member States in May 2004.
} 
countries, by age group, gender, sector and occupation. We also consider the degree of involuntary part-time work for each of these categories. The second half of the paper turns to consideration of the role that economic policy has played in encouraging part-time work within EU countries. In Section 4, we first outline some of the main regulations and institutions that have a direct or indirect impact on the possibility or incentive to work part-time. Section 5 then uses a panel econometric setting to analyse and quantify the effect of labour market policy, as measured by institutions and regulations, on the rate of part-time work. Section 6 concludes.

\section{The determinants of part-time work - A survey of the literature}

Broadly speaking, the literature on part-time job developments to date can be divided into two main branches. The first branch relies on micro-econometric analysis based on firm surveys. The purpose of this branch is to identify the determinants of part-time work (Haskel et al., 1997; Houseman, 2001; Euwals and Hogerbrugge, 2004) to illustrate the role of part-time work as a flexible work arrangement (Haskel et al., 1997; Faber, 1999), or to explain the transition between part-time jobs and other labour market states (Blank, 1994; O'Reilly and Bothfeld, 2002). Studies by, for example, Long and Jones (1981), Nakamura and Nakamura (1983) and Blank (1988) investigated the determinants of the choice to work part time at one point in time, finding that women with younger children, more children and higher levels of non-labour income were more likely to work part time. A larger number of studies examined wage differentials between full and part-time staff, for example Nakamura and Nakamura (1983) and Blank (1990), which typically found that equivalent part-time workers earn less per hour than their full-time counterparts, although the size of the measured effect varies across occupations.

A number of studies of part-time employment for individual countries exists. For example, Blank (1994) uses 14 years of data from the PSID to explore dynamic labour supply choices in the US among adult women between full-time, part-time and no labour market work. Her results indicate that past history is a very important predictor of current labour supply. Furthermore, most women use part-time work as a temporary alternative to full-time work or to being out of the labour market. Only for a small proportion of her female sample is part-time work used as a stepping stone to full-time employment. Doris (1998) studies the determinants of the growth in part-time work in Ireland over the 1980s, concluding that the growth in part-time work was predominantly supply-led and that the growth of the services sector facilitated this increase.

The second branch of literature considers part-time employment developments based on macro-data and includes sociological and institutional qualitative evidence (Smith et al., 1998; Delsen, 1998; OECD, 1998; Walwei, 1998). In the same vein some papers have focused on international comparisons (Lemaitre et al., 1997) and attempted to understand the reason why 
part-time work is so low in some countries such as Spain and Portugal (Ruivo et al., 1998), or so different across countries (Pfau-Effinger, 1998).

The present paper belongs to this second branch of the literature, whilst extending it to consider explicitly the effect of national policy on part-time work through the use of a country panel of time-varying institutions and structural variables. This latter methodological approach can be associated with another branch of the labour market literature - initiated by Scarpetta (1996) and extended by Belot and van Ours (2000), Blanchard and Wolfers (2000) and Nickell et al. (2002) - which uses cross-sectional or pooled cross-sectional data on indicators of labour market performance and labour market institutions to account for unemployment differentials across countries.

\section{Trends in part-time work in EU countries}

We begin our analysis with a description of the main trends in part-time employment. A growing part-time employment share has been a main feature of a number of industrialized countries over the past two decades. Figure 3.1 shows a significant increase in the share of part-time employment in total employment in the EU, Japan and Canada during the late 1980s and 1990s, while the US experienced a slight fall in the part-time employment share. In the EU, the parttime employment rate increased from 13 per cent in 1983 to 18 per cent in 2001.

However, there are still remarkable differences in the relative sizes of the part-time employment share by country within the European Union. The Netherlands currently exhibits the highest rate of part-time work, with 42 per cent of its workers working part time. A second group of EU countries, that is, Denmark, Belgium, France, Germany, Ireland, Austria, Sweden and the UK, currently have relatively high part-time employment shares, between 16 and 25 per cent. Relatively low rates of part-time work are found in Finland, Luxembourg and Portugal at around 11 per cent, in Italy and Spain at 8 per cent, and are lowest in Greece at 4 per cent (Figure 3.2).

All EU Member States except Denmark, Sweden and Greece have experienced an increase in their part-time employment share over the past two decades (1983-2002), ranging from an average increase of 0.1-0.2 percentage point per year in Finland and Spain $^{3}$, to 1.2 percentage points per year in the Netherlands. Figure 3.3 shows the development of part-time employment shares by country over the period 1983 to 2002 .

The part-time employment share is currently highest for 15-24 year olds, at nearly 23 per cent on average within the EU, and lowest for prime age workers (those aged 25-49) at just over 16 per cent (Figure 3.4). Older workers have a part time employment share of 21 per cent. Over the Union as a whole, only around 3 per cent of employed men of prime working age (24-49)

\footnotetext{
${ }^{3}$ OECD data is used for Finland instead of LFS, as LFS series are not available. The period is 1987-2002 for Spain.
} 
were in part-time jobs. This contrasts with the figure of over 25 per cent for young men aged 15 to 19. This pattern of a high part-time employment rate for young and older workers, relative to prime-age workers, holds across countries, with the exception of Austria, Germany and Portugal which exhibit low rates of part-time work among the young relative to other age groups, and Luxembourg, where the share of part-time employment is similar across age groups. Young workers also experienced the fastest rate of growth in part-time work during the 1990s within the EU as a whole, although the growth rate has flattened out more recently.

A breakdown of part-time work by gender reveals that part-time workers are more likely to be women (see Figure 3.5), with the EU average female part-time employment rate at 34 per cent and the male rate at 6.2 per cent in 2001 . This pattern of a significantly higher rate of female part-time employment holds across time and for all EU countries. Since the early 1990s, growth in part-time work has also generally been strongest amongst female workers, although Denmark, Sweden, and more recently France, have experienced declining female part-time employment rates. Rates have remained broadly unchanged for the UK.

A considerable variation in the rate of part-time work by occupation is also evident. The part-time employment share for the EU-15 (see Table 3.1, panel a) is high for elementary occupations, service workers, and shop and sales workers, at around 34 per cent. It is also relatively high for clerks at 24.3 per cent. On the other hand, craft and related trades workers, plant and machine operators, assemblers and legislators-top officials all have low shares of parttime employment - between 4 and 6 per cent in 2001. The first group experienced the strongest increase in the part time rate between 1992 and 2001, while the second group saw the smallest growth (Table 3.1 panel b). These results by occupation may reflect the role of both sectors and skill levels. Indeed, elementary occupations, service workers, shop and sales workers are strongly concentrated in highly part-time-intensive sectors (that is, services as seen in Table 3.1, panel c) while craft and related trades workers and plant and machine operators and assemblers are likely to be more present in less-part-time-intensive sectors (that is, industry). The part-time employment rate for high-skilled occupations such as legislators, professionals and technicians and associate professionals is below the average across all occupations, whilst it is significantly higher for low-skilled service occupations. Skill or educational level may well be negatively correlated with the part-time employment share.

The majority of part-time work within the EU is described by its workers as voluntary. Nevertheless, 14.2 per cent of part-time workers were working part-time involuntarily in the EU in 1992, with this share rising to 19.1 per cent in 1997 , before falling back to 14.4 per cent in 2001 (Figure 3.6a). There is also considerable variation in the share of involuntary part-time work by country and over time. For example, 44 per cent of part-time workers reported working involuntarily in Greece in 2001, compared to only 2.3 per cent in the Netherlands. It seems that the share of involuntary part time work is negatively related to the rate of part-time employment (see Figure 3.6b), although a number of countries have exhibited a downward trend in the share 
of part-time employment reported as involuntary since the second half of the 1990s (see Figure 3.7). The share of involuntary part-time employment appears to be cyclical, that is, higher in troughs of economic activity and lower during peaks in the business cycle. This would suggest that part-time employment might follow a cyclical pattern as well.

Investigation of the proportion of involuntary part-time work by age group and gender (Figures 3.7 and 3.8) highlights prime age part-time workers as historically most likely to label their employment status as involuntary across all countries. 9.5 per cent of prime age part-time workers in the EU in 2001 reported their part-time status as involuntary. Shares of involuntary part-time employment tend to be significantly lower amongst young and older age groups, with as little as 2.5 per cent of workers in these groups reporting involuntary part-time work in the EU in 2001. Involuntary part-time workers are also more likely to be male, with 20 per cent of male workers, compared to 13 per cent of female workers, labelling their part-time status as involuntary for the EU in 2001. This pattern of a higher incidence of involuntary part-time employment for men is generally found across countries, with the exception of Portugal, Finland and Denmark, where the female rate is higher than the male, and Spain, where the male and female rates are very close. Shares of both male and female involuntary part-time work exhibit variation over time ${ }^{4}$.

The stylized facts presented in this section support the view that part-time employment represents an important opportunity for particularly young, older and female workers to enter the labour markets of the European Union. The rate of part-time work is clearly higher for these groups relative to prime-aged males, a pattern found to be broadly consistent across countries. Furthermore, for the vast majority of workers in these groups, the decision to work part-time has been a voluntary one, which is all the more satisfactory in terms of welfare maximization. However, as these stylized facts have stressed, both the level of part-time rate and its development over time varies strongly across the countries of the EU. This suggests that crosscountry differences in policy setting and institutions, together with other national structures (sectoral, demographic and societal), play an important role in the incidence of part-time work. The remainder of the paper focuses on an investigation of these latter influences.

\footnotetext{
${ }^{4}$ The existence of involuntary part-time employment raises the question to what extent part-time jobs facilitate entry to the labour market and offer opportunities for career development. O'Reilly and Bothfeld (2002) and Buddelmeyer, Mourre and Ward (2004a), exploiting micro-data, find that the stepping stone effect of part-time employment remains quite limited, which suggests that involuntary part-time employment contributes to the segmentation of European labour markets.
} 


\section{Regulations towards part-time work in EU countries}

The regulatory and institutional framework varies considerably across countries of the EU and may represent an important influence on the cross-country development of part-time employment. A number of types of regulation may have a direct or indirect effect on the rate of part-time work. This section aims both to introduce the key regulations affecting working time across EU countries and to outline how such regulations differ across countries.

A number of regulations affect the rate of part-time work directly. This first set of regulations is legally binding and limits the use of part-time work. For instance, labour laws may give the employer the right to deny an employee's request to work part-time under certain circumstances. Certain types of regulation may however facilitate the conversion of full-time jobs into voluntary part-time employment in order to reconcile personal and professional lives (Genre et al., 2003).

A second set of regulations affects part-time employment indirectly through shifting the financial incentives for firms to offer part-time opportunities and also for employees to accept them. For example, wage regulation (including the regulation of working time premia for shiftwork or overtime), social protection systems and tax and benefit systems fall into this group. In some countries, for example Portugal, hourly wages for part-time and full-time work are restricted by law to be equal (pro rata clause). Moreover, hours or earnings thresholds for social insurance contributions (above which contributions to social security schemes become payable and workers become eligible for social benefits) and special subsidies or tax rebates for firms hiring part-time staff may influence the structure of non-wage costs for employers and therefore also indirectly influence the rate of part-time work. For example, during the period 1993-2000, special social security contribution rebates and reductions were granted to firms hiring part-time workers in France. This coincided with a boom in part-time employment over the same period. Similarly, changes in hours and social security thresholds may also influence the supply of parttime work. For example, in Spain, a relaxation in working hour legislation, together with a reduction in social security contributions for part-time workers in 1994, resulted in a strong increase in the part-time employment rate between 1994 and 1995. However, lower pension entitlements may restrict the labour supply of part-time jobs (Ginn and Arber, 1998).

Table 4.1 summarises the main regulations affecting part-time work (through law or collective agreement) that have been adopted by some EU countries in recent years. A couple of interesting patterns emerge from this table. First, most of the reforms undertaken have been targeted at encouraging the use of part-time work by firms, either through a relaxation in the conditions of use of part-time jobs or through the granting of subsidies. Second, towards the end of the 1990s some countries adopted regulatory measures to address the overall job quality offered by part-time positions in terms of wages relative to full-timers, career development 
opportunities, access to training and so on. These measures followed the signature of a European framework agreement on part-time work on 6 June 1997 by the European Trade Union Confederation (ETUC), the Union of Industrial and Employers' Confederations of Europe (UNICE) and the European Centre of Enterprises with Public Participation and of Enterprises of General Economic Interest (CEEP), in the presence of social affairs Commissioner Padraig Flynn $^{5}$.

Consideration of Table 4.1 by country reveals a fairly different situation across the EU. Four groups can be tentatively considered. First, in as early as 1982, the Netherlands adopted a tripartite agreement aimed at an efficiency-enhancing redistribution of existing employment through, among other measures, working time reduction and part-time work. A second group of countries (Belgium, Finland, France and Spain) adopted new regulation to foster the development of part-time work in the mid-1990s as a possible remedy to high unemployment. A third group (Austria, Germany and Italy) took regulatory steps in the late 1990s to help part-time work developments. Finally, countries such as Greece, Ireland, Luxembourg, Portugal and Sweden have not adopted specific legislation to encourage part-time work.

A third set of regulations and institutions influence employment in general, but may have an indirect bearing on part-time employment in particular. First, for mothers with young children it has been argued that the probability of (re-)entering the labour market, either in the form of full-time or part-time employment, is strongly linked with the system of child benefit/care arrangements in place. In general, the provision of child benefits can create an "unemployment trap" if benefits are means tested ${ }^{6}$. Moreover, some child benefit systems grant additional income to parents who renounce work in order to take care of their young children ${ }^{7}$. On the other hand, the lack of affordable (subsidized) childcare may represent a major disincentive to taking up employment.

Similarly, unemployment benefit systems (together with other benefits) may create an 'unemployment trap' through high net replacement rates and long benefit duration. Doudeijns (1998) studied the financial disincentive to work created by unemployment benefits, finding it had a significantly negative impact on the decision to take up part-time employment. However,

\footnotetext{
5 The agreement seeks to establish a general framework for the elimination of discrimination against part-time workers, and hopes to contribute towards the development of opportunities for part-time working on a basis which is acceptable to employers and workers alike.
}

${ }^{6}$ If child care benefits are means tested, then additional income from work is partially (or completely) offset by a reduction in this benefit, thereby reducing the incentives to increase labour supply. Generally speaking, the net gains to family income may then be just too small to make the effort worthwhile. How large these disincentive effects are depends on the actual design of the benefit.

\footnotetext{
${ }^{7}$ Such measure was in place in France in the 1990s ('Allocation Parentale d'Education'). It has been shown to have
} a strong adverse effect on female participation (Laroque and Salanié, 2003). 
the recent development of 'in-work benefits', the tightening of benefit eligibility criteria and the enhanced controls over their implementation should all help towards alleviating this disincentive.

Tax systems, and in particular high income tax rates, may also deter part-time work through creating a financial disincentive for individuals to enter the labour market. Such a disincentive is reinforced when income tax is computed on the basis of a couple's earnings, rather than on an individual's, since in such a system the second earner in a couple may face a relatively high effective marginal rate. Dependant partner's allowances may make the decision to take up a job even harder, especially a low-paid part-time job, which would results in the loss of such a benefit.

Relatively strict employment protection legislation (EPL) has become a more and more important reason for hiring part-time employees. This is because part-time jobs may fall outside the sphere of regular contract EPL and may therefore offer employers the opportunity to bypass such legislation. In the late 1990s, in a context of increasing competition and uncertainty, firms realized the advantages of 'atypical jobs', which were and continue to be considered more flexible and less expensive. Part-time employment was quickly acknowledged as offering these advantages, together with temporary jobs, help agency employment, shift work, on-call jobs and atypical working time jobs (nights and weekends). Bentolila and Dolado (1994) labelled this new search for flexible staffing arrangements as the 'new reasons' for hiring part-time workers.

This section has outlined both the number and type of labour market regulations and institutions that may affect the rate of part-time work. Some of these regulations affect part-time work directly and others indirectly. Furthermore there has been considerable variation in the extent and type of regulation applied across countries of the EU. The conclusions of this section therefore give good reason to think that part-time policies and other labour market institutions have contributed to explaining the growth in part-time employment in some EU countries. In order to quantify such effects the next section moves onto a panel econometric setting.

\section{The effect of regulations and labour market institutions on part-time employment}

This section focuses on quantifying the effect of labour market policy, as measured by institutions and regulation, on the development in the part-time employment rate (PTR - that is, share of those working part-time in total employment).

\subsection{Data and estimation strategy}

The part-time employment rate, as well as the share of involuntary part-time employment, was taken for each country from employment series reported in the annual European Community 
Labour Force Surveys, compiled by Eurostat. Data are generally available annually from 1983 to $2002^{8}$ for most of the EU countries, except Portugal (from 1986), Spain (from 1987) and Austria, Finland and Sweden (from 1995) ${ }^{9}$.

In order to capture the effect of part-time regulation on the part-time rate, we have created a vector of country-specific trends which starts from the year in which regulations of part-time employment were relaxed in each country ${ }^{10}$. The motivation for the creation of this variable is that we wish to capture the additional annual increase in part-time employment rate that follows the change in part-time regulation ${ }^{11}$. The starting date of each trend therefore varies by country and is identified by systematically exploiting the information reported in Table 5.1. For the countries where part-time regulation has not changed (Ireland, Portugal, Sweden and the United Kingdom), the value of the variable is set to zero for the complete period 1983 to 2001. To avoid an 'outlier' bias, we have also constructed the 'policy' variable excluding the trend for the Netherlands ${ }^{12}$.

Data on general labour market institutions are taken from the recent macroeconomic literature on labour markets (such as Nicoletti et al., 2000; Blanchard and Wolfers, 2000; Nickell et al., 2002). Most of these data on national labour market institutions are available only until 1997-98. We include variables to alternatively capture overall employment protection legislation (EPL) and EPL on temporary and regular contacts. An indicator for the provision of child benefits (drawn from Eurostat) is also used. Unemployment benefit replacement ratios and unemployment benefit duration are included to capture possible disincentive effects to take up a

${ }^{8}$ Since the preparation of this paper, data have been made available for 2002 . The trends displayed earlier in this article used data until 2001 only. The econometric estimations used data until 1998, as most of institutional data were only available up to this date.

${ }^{9}$ For some countries, such as Finland and Sweden, data have been back-cast using OECD Annual Labour Force Statistics, when available. Data are based on declaration of individuals on their working status (part-timers/fulltimers) rather than on a precise measure of hours worked. The data therefore represent the most harmonized existing sources on part-time work.

${ }^{10}$ Technically this vector corresponds to 'pooled after-reform country trends'. For each country we create a trend variable that takes the value of 0 prior to regulatory reforms, equals 1 in the first year following a reform to parttime regulation, equals 2 in the second year following reform and equals $n$ in the $n$th year following reform. We then stack the observations of this variable country by country to compose a vector. Given the relatively limited time-series dimension, we follow this stacking approach and restrict the coefficients to be the same across countries, rather than estimating each country block separately, in order to increase the efficiency of the estimate and to capture the overall effect of reforms.

${ }^{11}$ This impact on the change in PTR is likely to disappear in the long run, as it corresponds to the dynamic toward the new steady state implied by the reform of part-time regulation.

12 The Netherlands, which experienced a much sharper increase in part-time employment than the other EU countries, stood out clearly as an outlier within the EU (Euwals and Hogerbrugge, 2004). More technically speaking, as the change in the regulatory framework for part-time jobs occurred before the start of the sample (that is, 1982), the value of the 'policy' variable for the Netherlands cannot really measure the effect of the change in regulation. It would instead simply capture the time trend. 
part-time employment as a result of 'unemployment traps'. We also add the total labour tax rate, computed by the OECD and reported by Nickell et al. (2002).

Other variables capturing important characteristics of the labour market, and which are expected to influence the rate of part-time work, are also included in our specification. Such controls are the female participation rate, fertility rate, share of employment in services, schooling rate of the 15-25 population and the share of temporary jobs. Finally we include the output gap stemming from the OECD Economic Outlook database to capture the business cycle.

Our model considers the level in the part-time employment rate, across countries and over time, that can be attributed to structural factors and institutions. $\alpha_{\mathrm{i}}$ are $I$ country dummies and $\alpha_{\mathrm{t}}$ are $T$ time dummies. INST $T_{k}$ are $K$ variables capturing national policies and institutions and $C_{j}$ are $J$ variables representing controls (demographic, structural, macroeconomic or societal factors).

$$
\mathrm{PT}_{\text {it }}=\alpha_{i}+\alpha_{t}+\sum_{\mathrm{k}=1}^{\mathrm{K}} \mathrm{a}_{\mathrm{k}} \mathrm{INST}_{\mathrm{kit}}+\sum_{\mathrm{j}=1}^{\mathrm{J}} \mathrm{b}_{\mathrm{j}} \mathrm{C}_{\mathrm{jit}}+\varepsilon_{\mathrm{it}}
$$

This specification is close to that used by Nickell et al. (2001) to explain OECD unemployment, but the variables for short-term macroeconomic shocks (labour demand shock, real import price shock, real interest rate and so on) are replaced by the output gap. Moreover, the lagged dependent variable has been dropped as its presence introduces correlation between the errors and the regressors, which can bias the GLS estimate of parameters. However, as there is clear evidence of non-stationarity for many of the variables used in this equation, there is a risk of 'spurious regression'. We use the Maddala-Wu test to check out whether there are unit roots in the residual of the equations. The test clearly rejects the hypothesis of the residuals having a unit root, which indicates the presence of cointegration relation between the variables.

As some heteroskedasticity and first order autocorrelation are detected, all regressions are estimated by feasible generalized least squares. To tackle possible endogeneity problems and checking for robustness, we also applied an instrumental variable method (the two-stage least squares within estimator). The presence of endogeneity may be particularly problematic in the case of the relationship between the part-time employment rate and participation, or between part-time employment and EPL, where the causality is likely to go both ways. Lacking alternatives, we instrument the structural and institutional variables by their values lagged by two years.

\subsection{Results}

As shown by Table 5.1, a number of findings for the group of European countries that emerge from equation 1 are confirmed when using instrumental techniques (equation 7). 
The change in part-time regulation turns out to have a very strong and significant impact on parttime employment developments. This still holds true when excluding the Netherlands, although the magnitude of the effect decreases somewhat. Thus we conclude that the relaxation of regulations towards part-time work in the EU countries has had a significantly positive effect on the development of the PTR.

Child benefits exert a strong negative and highly significant effect on the PTR. Thus child benefits act as a disincentive to working part time and make it less likely for individuals to (re-)enter the labour market through part-time employment. The reasoning behind this phenomenon may be that benefits alter the trade-off between work and leisure towards a more family-oriented life.

While overall EPL is only significant at a 10 per cent level, EPL on regular jobs is highly significant and has a strong and positive effect on the PTR. Conversely, EPL for temporary jobs is either insignificant or negatively related to the PTR.

Unemployment benefit replacement ratios are found to be negatively correlated with the PTR, but their statistical significance is not robust across estimated equations. Unemployment benefit duration seems to impact the PTR only modestly and its effect is estimated with little precision.

Although total labour taxes appear to affect positively the PTR in Table 5.1, this result is not robust when using other specifications (Buddelmeyer, Mourre and Ward, 2004b). This reflects the theoretical uncertainty as regards the overall impact of labour taxes on employment (for example, income versus substitution effects). Moreover, the total labour tax rate remains too crude and aggregate an indicator to fully identify the specific effect on part-time employment, which would require knowing the relative tax burden borne by part-timers compared to fulltimers.

Most controls turn out to be significant and of expected sign. The female participation rate is positively related to PTR. The rise in female participation has resulted in an increase in the part-time rate in many countries, which appears to have been used as the main way of integrating women into the labour market. Similarly the fertility rate and the schooling rate of the 15-25 population are also found to affect the PTR positively, and particularly in the case of the fertility rate, strongly. The share of employment in the service sector is revealed as a particularly powerful determinant of the rate of part-time work. This ties in with our analysis of the trends in part-time work in Section 3 which highlighted that a high proportion above of part-time jobs are within the service sector. The impact of the output gap is negative and significant in most equations, confirming earlier results from Buddelmeyer, Mourre and Ward (2004b). Conversely the temporary employment rate is found to have a positive influence on the PTR, which suggests the absence of substitution between part-time employment and temporary employment, and that these two flexibility schemes are complementary in circumventing the rigidity of European labour markets. 
The coefficients provided by Table 5.1, allow us to say something about the relative size of the contribution made to the PTR by time work regulations and general labour market institutions. Although providing insightful order of magnitudes, these results are largely speculative and should be interpreted with considerable caution on the basis of previously outlined caveats regarding endogeneity. Furthermore, their application to future periods is subject to the Lucas critique. Our results suggest that changes in part-time regulation of a similar type and applied at a similar rate to those recorded in the past (as captured by a time trend following the reform) would induce an additional rise of PTR of between 0.16 and 0.35 percentage points on average each year - see columns (2) and (3) in Table 5.1 - which amounts to between 1.6 and 3.5 percentage points rise after ten years. It follows that more effective policies or a faster pace of reform could entail larger rates of increase. With regard to institutions having an indirect effect on the PTR, our results reveal that a switch from the extreme case of no EPL regulation on regular contracts to the opposite situation of extremely stringent EPL ${ }^{13}$ increases the PTR by around 11-15 percentage points. This implies that the future PTR will be sensitive to changes in EPL, although the effect might materialize with some lag. Furthermore our results suggest that a decline in the proportion of child benefits in GDP by 1 percentage point could lead to an increase in PTR of around 1.5 percentage points, while conversely a decline in unemployment benefit replacement ratios by 1 percentage point would result in a weak increase in the part-time rate (of around 0.02-0.03 percentage point). Our results reveal the potentially strong impacts that other factors, if they continue, may have on the PTR. For example, an increase of 10 percentage points in the female participation rate, or in the share of service employment, would increase the PTR by around 3-4 percentage points and 2-3 percentage points, respectively, while a strong rise in the fertility rate of 0.5 percentage point would contribute to increasing the PTR by around 2.5 percentage points.

\section{Policy conclusions}

Our results indicate that the both the development of the part-time employment rate over time and the variation in the PTR across countries are significantly affected by institutional and policy changes. In particular policy measures geared toward encouraging part-time work are found to be positively related to actual part-time developments. These measures include both the legal framework affecting part-time positions and the creation of financial incentives (subsidies and improvement of social protection) to take up a part-time job. Moreover, other labour market institutions, including benefit systems, are found to significantly but indirectly influence the

\footnotetext{
${ }^{13}$ This corresponds to Level 0 and Level 6, respectively, of the EPL variable computed by the OECD (Nicoletti et al., 2000).
} 
growth in part-time work. For instance, the stringency of employment protection legislation for regular contracts favours part-time work, suggesting that part-time employment may be firms' response to rigid labour markets. Furthermore, child benefits and, to a lesser extent unemployment benefit generosity and duration, may hinder the increase in the part-time rate through the disincentive to take up employment that they induce. Consequently, further reforms of labour market institutions can be expected to facilitate growth in part-time employment and thereby to pull more people into paid employment.

Our analysis shows that such reforms can contribute to meet the employment targets set for 2010 at the 2000 Lisbon Council meeting. Currently the low female and total employment rates in some EU countries require considerable efforts in order to succeed. Evidence from the boarder economic literature to date has shown that the increase in female participation and the increase in part-time employment seem to go hand in hand. Our results indicate that targeted policy to facilitate part-time employment represents a promising avenue worthy of further exploration. The increase in the proportion of part-time employment can be expected to continue, because its main driving forces (employers' desire for flexibility, service sector expansion, women's increased labour market participation and so on) are likely to persist in the medium to long run. Part-time work developments are also expected to disproportionately benefit the relatively underemployed age groups of young and older workers. Keeping more older workers in the workforce by offering part-time work solutions would also help to reduce the finanacial burden of an ageing population.

In addition to raising the employment rate in the European Union, part-time employment gives employers greater flexibility in adjusting working hours to business requirements while achieving higher productivity. If freely chosen and protected by law, part-time jobs also offer workers a good way of striking a balance between their professional and private lives. Furthermore, in some cases part-time work can be a stepping stone towards permanent employment. In comparison we have found that the share of involuntary part-time employment (that is, underemployment) is negatively related to the rate of part-time employment. However, albeit fairly low, the share of involuntary part-time employment remains non-negligible. Policies designed to promote part-time work by lowering its labour costs relative to that of full-time employment are likely to have the perverse effect of increasing further the proportion of involuntary part-time work, with negative consequences for women and other workers already at a disadvantage in the labour market. This segmentation of the labour market may suffer lower hourly remuneration, poverty traps, insufficient access to training and lack of career developments, which in turn negatively affect their long-term productivity. Thus, in order to be fully effective, employment policy should support and protect the bases for voluntary part-time and full-time work. 


\section{References}

Belot, M. and J. van Ours (2000), 'Does the Recent Success of Some OECD Countries in Lowering Their Unemployment Rates Lie in the Clever Design of Their Labour Market Reforms?', CEPR Discussion Paper No. 2492.

Bentolila, S. and J.J. Dolado (1994), 'Labour Flexibility and Wages: Lessons from Spain', Centro de Estudios Monetarios y Financieros: Documento de Trabajo No. 9404.

Blanchard, O. and J. Wolfers (2000), 'The role of shocks and institutions in the rise of European unemployment: the aggregate evidence', Economic Journal, 78 (2), 182-7.

Blank, R.M. (1988), 'Simultaneously modelling the supply of weeks and hours of work among female household heads', Journal of Labor Economics, 6 (2), 177-204.

Blank, R.M. (1990), 'Are part-time jobs bad jobs?', in G. Burtless (ed.), A Future of Lousy jobs? The Changing Structure of US Wages, Washington, DC: The Brookings Institute, 123-55.

Blank, R.M. (1994), 'The Dynamics of Part-time Work', NBER Working Paper No. 4911.

Buddelmeyer, H., G. Mourre and M. Ward (2004a), 'Part-time work in EU countries: labour market mobility, entry and exit', forthcoming in the ECB Working Paper Series.

Buddelmeyer, H., G. Mourre and M. Ward (2004b), 'The determinants of part-time work in EU countries: empirical investigations with macro-panel data', European Commission Economic Paper No. 213 and IZA Discussion Paper No. 1361.

Delsen, L. (1998), 'When do men work part-time?', in Jacqueline O'Reilly and Colette Fagan (eds), Part-time Prospects: An International Comparison of Part-time Work in Europe, North America and the Pacific Rim, London and New York: Routledge, 57-76.

Doris, A. (1998), 'Married women in the Irish part-time labour market', Economic and Social Review, 29 (2), 157-78.

Doudeijns, M. (1998), 'Are benefits a disincentive to work part-time?', in Jacqueline O'Reilly and Colette Fagan (eds Part-time Prospects: An International Comparison of Part-time Work in Europe, North America and the Pacific Rim, London and New York: Routledge, 116-36.

Euwals, R. and M. Hogerbrugge (2004), 'Explaining the Growth of Part-time Employment: Factors of Supply and Demand', IZA Discussion Paper No. 1124.

Faber, H.S. (1999), 'Alternative and part-time employment arrangements as a response to job loss', Journal of Labor Economics, 17, S142-69.

Genre, V., R. Gómez-Salvador, N. Leiner-Killinger and G. Mourre (2003), 'A widening scope for non-wage components in collective bargaining in the EU?', in G. Fagan, J. Morgan and F.P. 
Mongelli (eds), Institutions and Wage Formation in the New Europe, Cheltenham, UK and Northhampton, MA, US: Edward Elgar, pp. 134-73.

Ginn, J. and S. Arber (1998), 'How does part-time work lead to low pension income', in Jacqueline O'Reilly and Colette Fagan (eds), Part-time Prospects: An International Comparison of Part-time Work in Europe, North America and the Pacific Rim, London and New York: Routledge, 156-74.

Haskel, J., B. Kersley and C. Martin (1997), 'Labour market flexibility and employment adjustment: micro evidence from UK establishments', Oxford Economic Papers, New Series, 49 (3), 362-79.

Houseman, S. (2001), 'Why employers use flexible staffing arrangements: evidence from an establishment survey', Industrial and Labor Relations Review, 55 (1), 149-69.

Laroque, G. and B. Salanié (2003), 'Participation, fertility and financial incentives in France', presented at ECB/CEPR Labour Market Workshop What Explains the Pattern of Labour Supply in Europe?, June, Frankfurt am Main, Germany.

Lemaitre, G., P. Marianna and A. Van Bastelaer (1997), 'International comparisons of part-time work', OECD Economic Studies, (29), 139-52.

Long, J.E. and E.B. Jones (1981), 'Married women in part-time employment', Industrial and Labor Relations Review, (34), 314-25.

Nakamura, A. and M. Nakamura (1983), 'Part-time and full-time work behaviour of married women', Canadian Journal of Economics, (16), 229-57.

Nickell, S., L. Nunziata, W. Ochel and G. Quintini (2001), 'The Beveridge Curve, Unemployment and Wages in the OECD from the 1960s to the 1990s', prelim. version, CEP Discussion Papers No. 502, Centre for Economic Performance, London School of Economics.

Nickell, S., L. Nunziata and W. Ochel (2002), 'Unemployment in the OECD Since the 1960s. What Do We Know?', Bank of England Discussion Papers, May.

Nicoletti, G., S. Scarpetta and O. Boylaud (2000), 'Summary Indicators of Product Market Regulation with an Extension to Employment Protection Legislation', OECD Working Papers No. 266.

O'Reilly, J. and S. Bothfeld (2002), 'What happens after working part-time? Integration, maintenance or exclusionary transitions in Britain and western Germany', Cambridge Journal of Economics, (6), 409-39.

OECD (1998), 'Working hours: latest trends and policy initiatives', Employment Outlook, 17388.

Pfau-Effinger, B. (1998), 'Culture or structure as explanations for differences in part-time work in Germany, Finland and the Netherlands', in Jacqueline O'Reilly and Colette Fagan (eds), Part- 
time Prospects: An International Comparison of Part-time Work in Europe, North America and the Pacific Rim, London and New York: Routledge, 177-98.

Ruivo, M. M.P. Gonzalez and J.M. Varejao (1998), 'Part-time work in Portugal and Spain', in Jacqueline O'Reilly and Colette Fagan (eds), Part-time Prospects: An International Comparison of Part-time Work in Europe, North America and the Pacific Rim, London and New York: Routledge, 199-213.

Scarpetta, S. (1996), 'Assessing the role of labour market policies and institutional settings on unemployment: a cross-country study', OECD Economic Studies, 2(26), 43-82.

Smith, L., C. Fagan and J. Rubery (1998), 'Where and why is part-time work growing in Europe?', in Jacqueline O'Reilly and Colette Fagan (eds), Part-time Prospects: An International Comparison of Part-time Work in Europe, North America and the Pacific Rim, London and New York: Routledge, 35-56.

Walwei, U. (1998), 'Part-time work: a threat to labour standards?', in Jacqueline O'Reilly and Colette Fagan (eds), Part-time Prospects: Part-time Prospects: An International Comparison of Part-time Work in Europe, North America and the Pacific Rim, London and New York: Routledge, 96-115. 
Figures and Tables

Fig. 3.1 Part-time employment rate (\%)

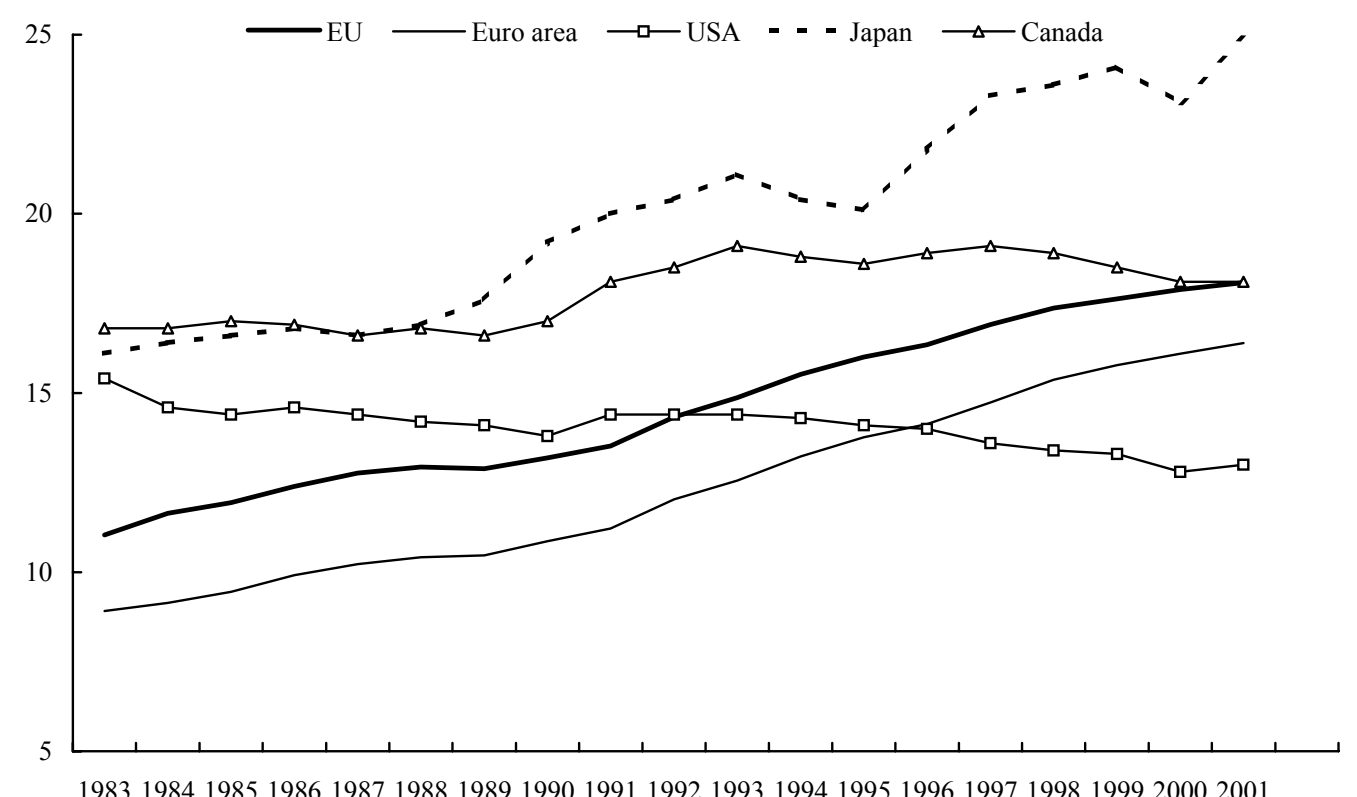

Sources: OECD, Eurostat (Labour Force Surveys).

Fig. 3.2 Part-time employment rate in 2001 (\%)

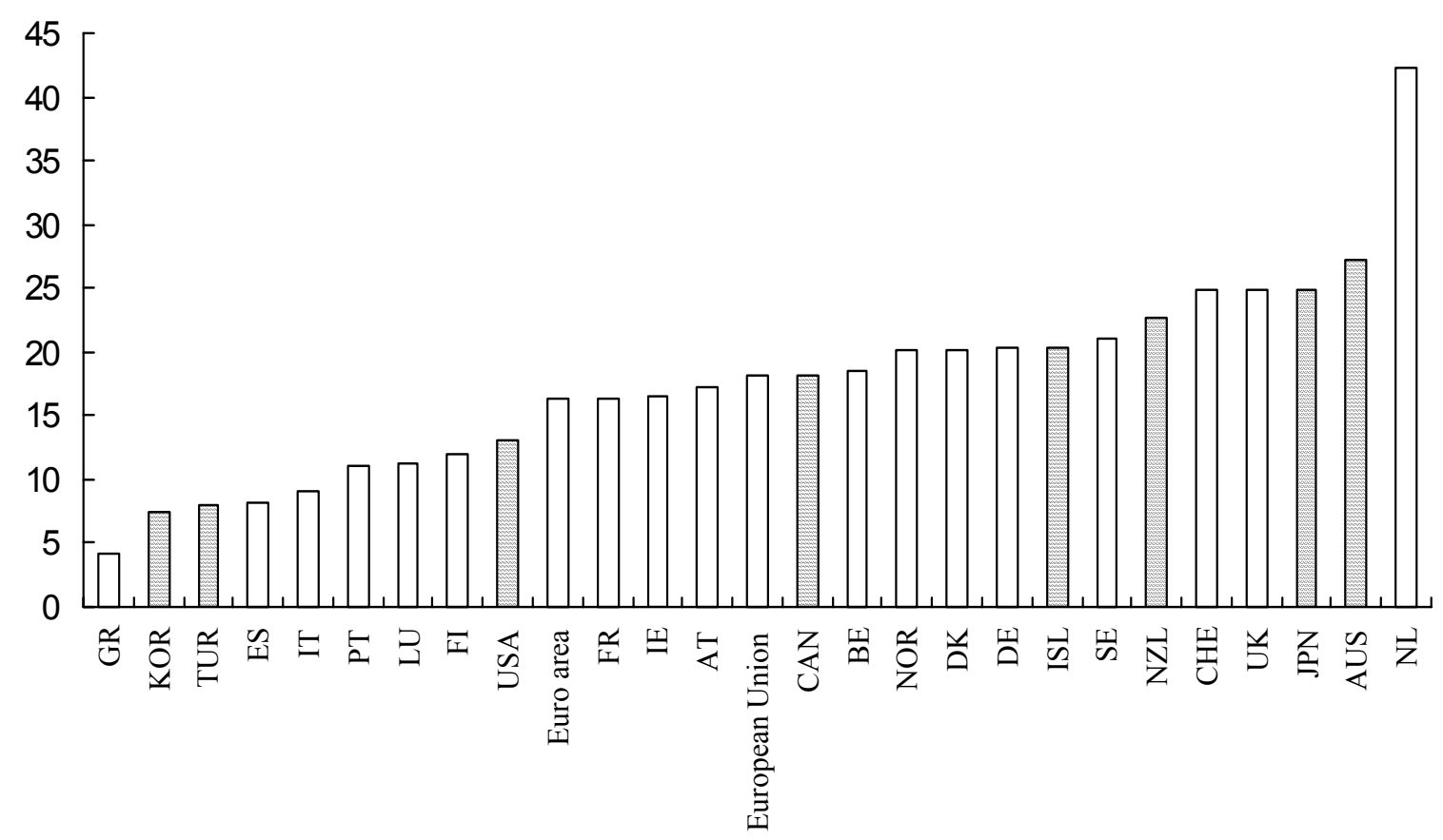

Sources: OECD, Eurostat (Labour Force Surveys).

Note: The shaded bars underline the non-EU countries. 
Fig 3.3 Part-time employment rate (\%)

Panel a Country with High rate

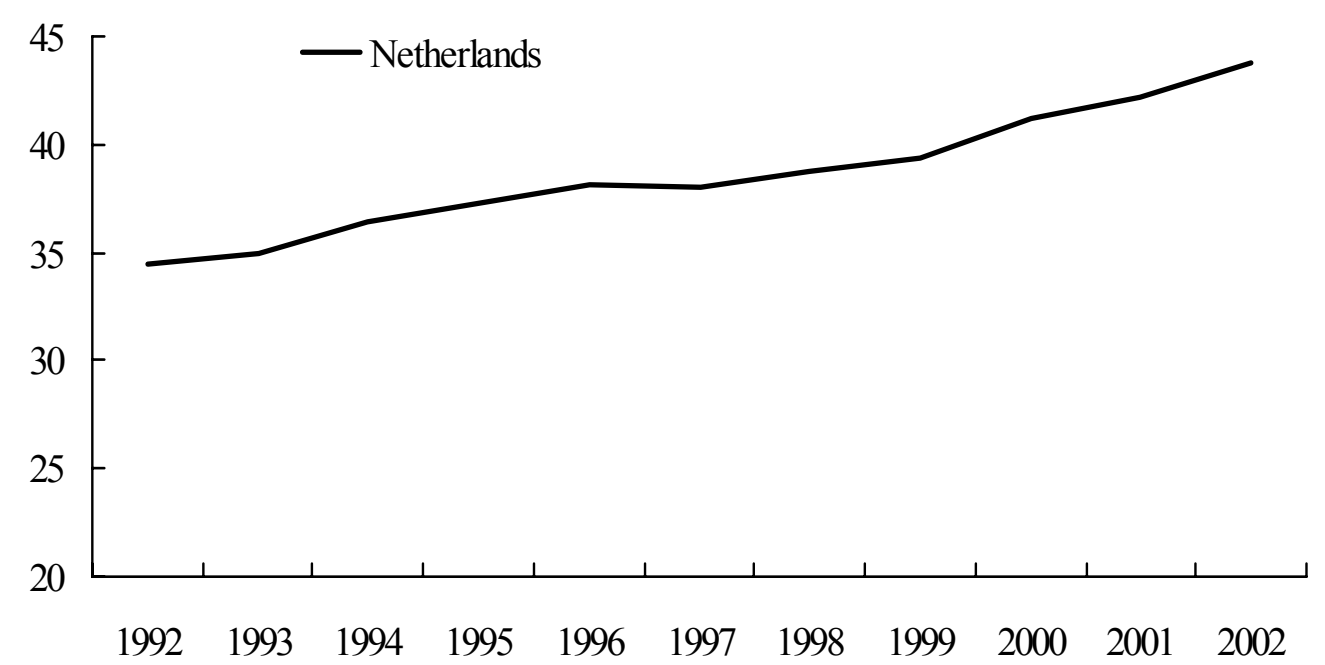

Panel b Country with Medium rates

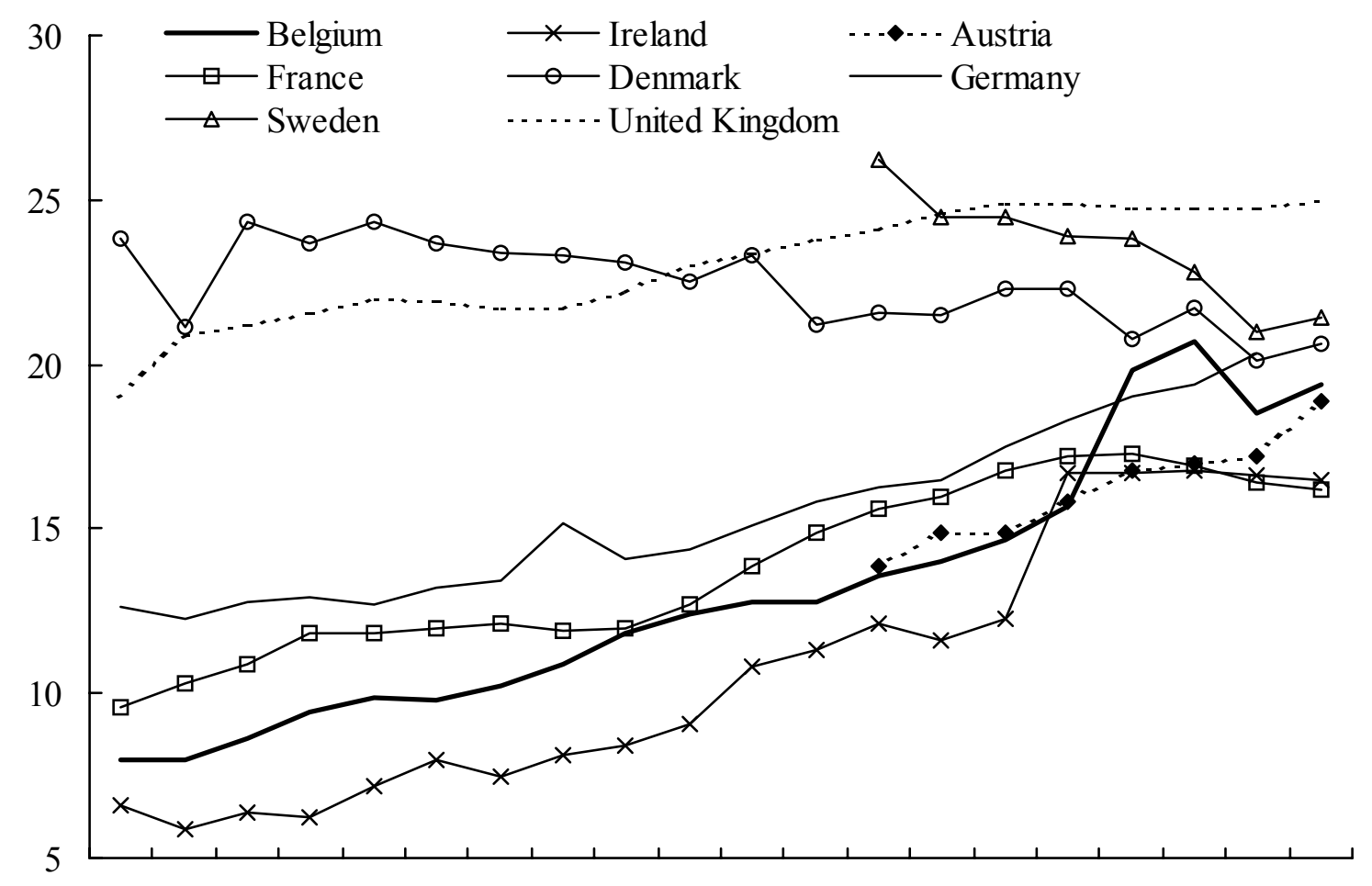

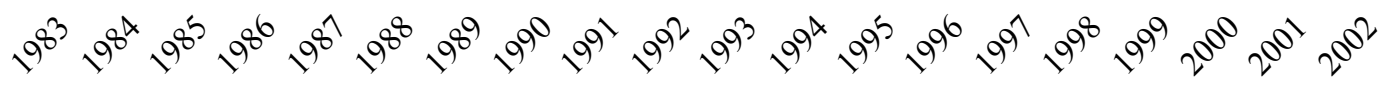


Panel c Countries with Low rates

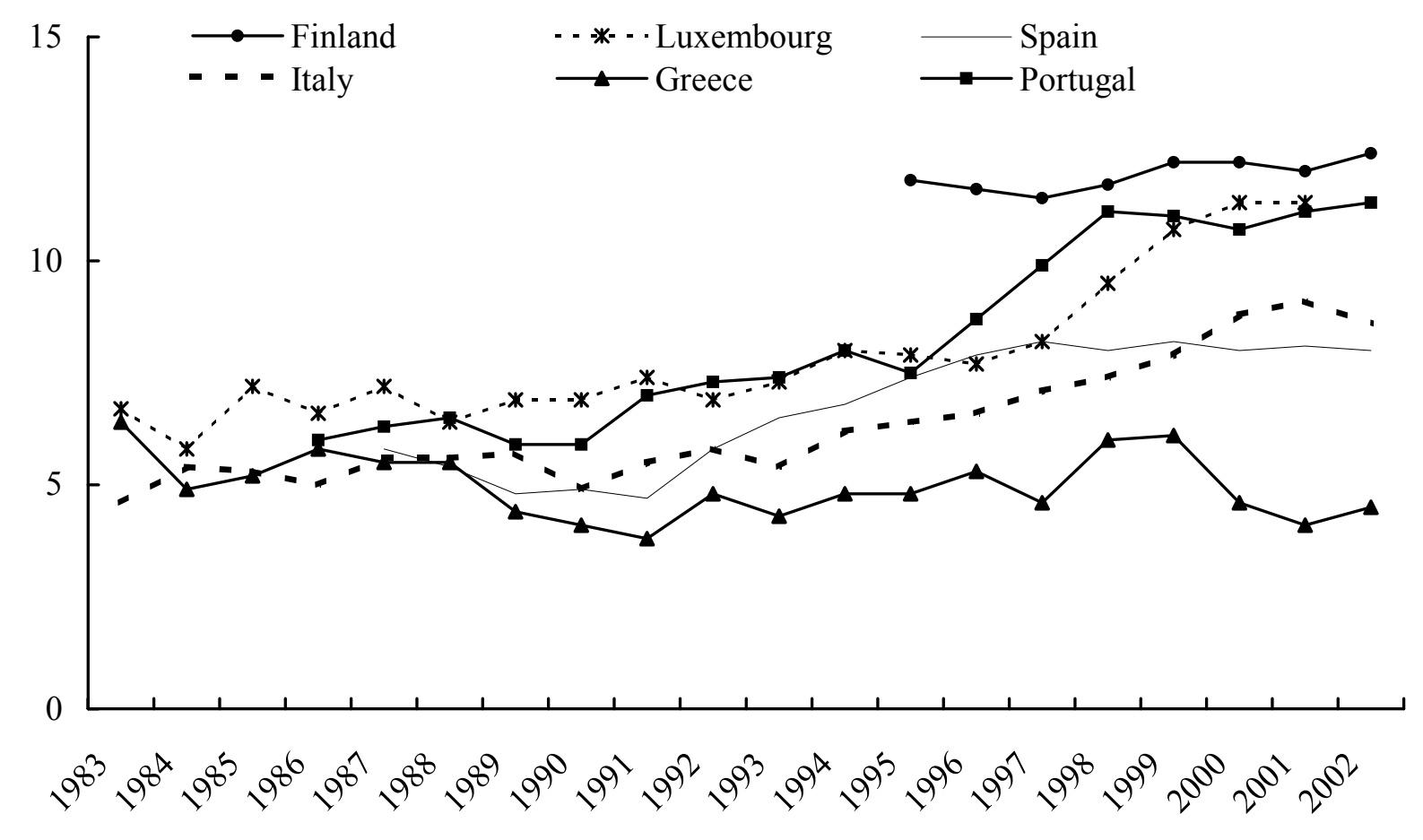


Fig 3.4 a Part-time employment rate by age group in the EU-15

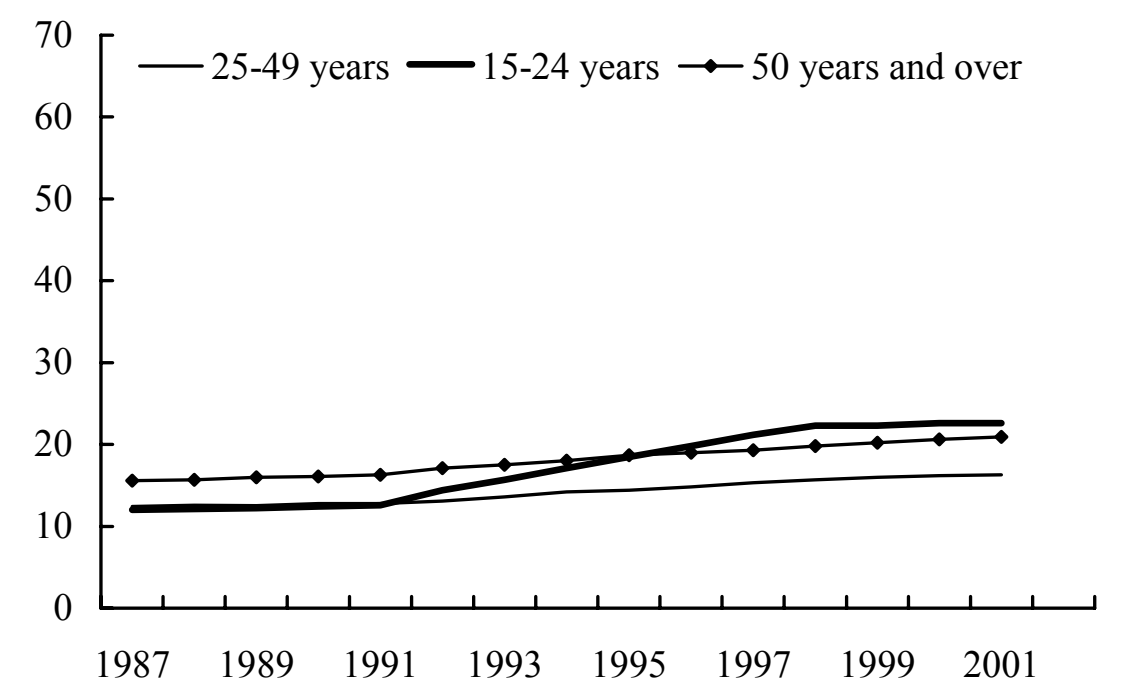

Fig 3.4 b Part-time employment rate by age group in EU-15 countries in 2001

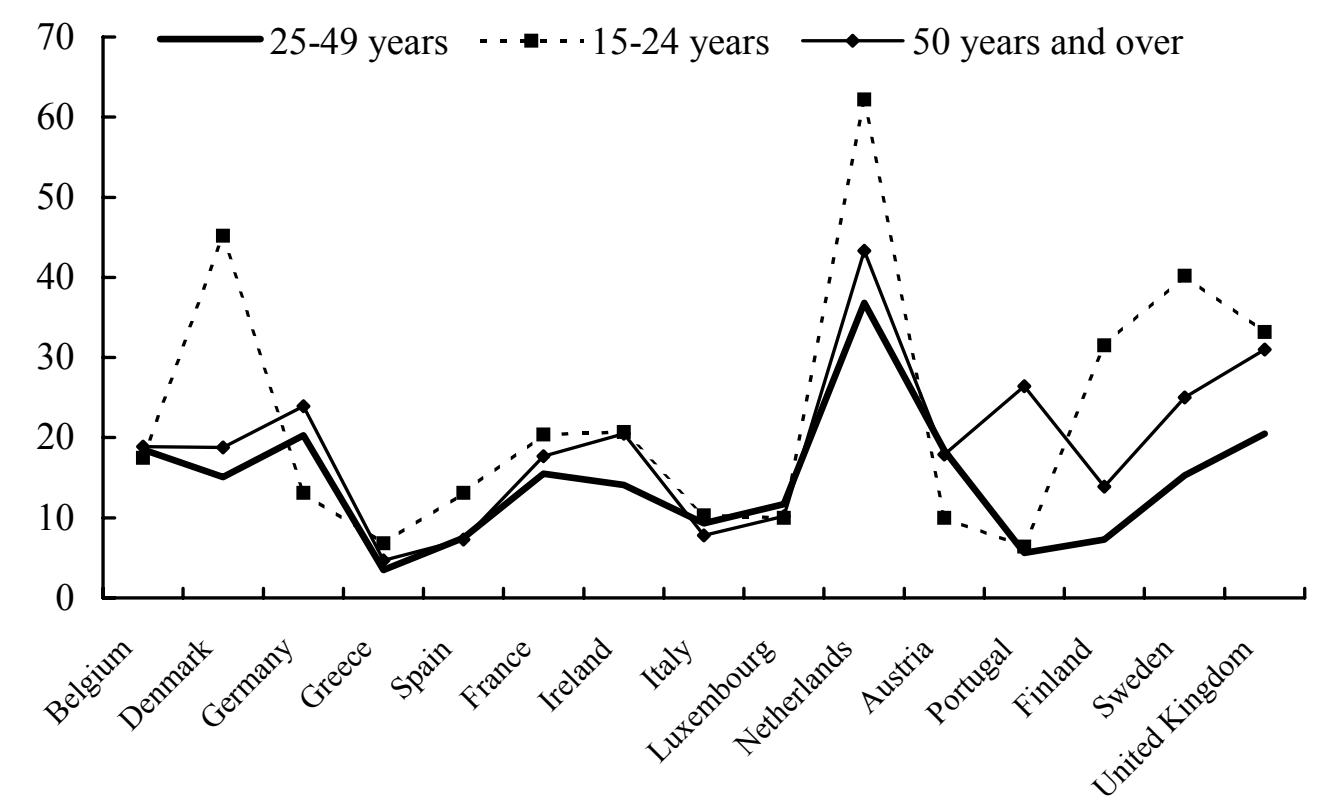


Fig 3.5 a Part-time employment rate by gender in the EU-15

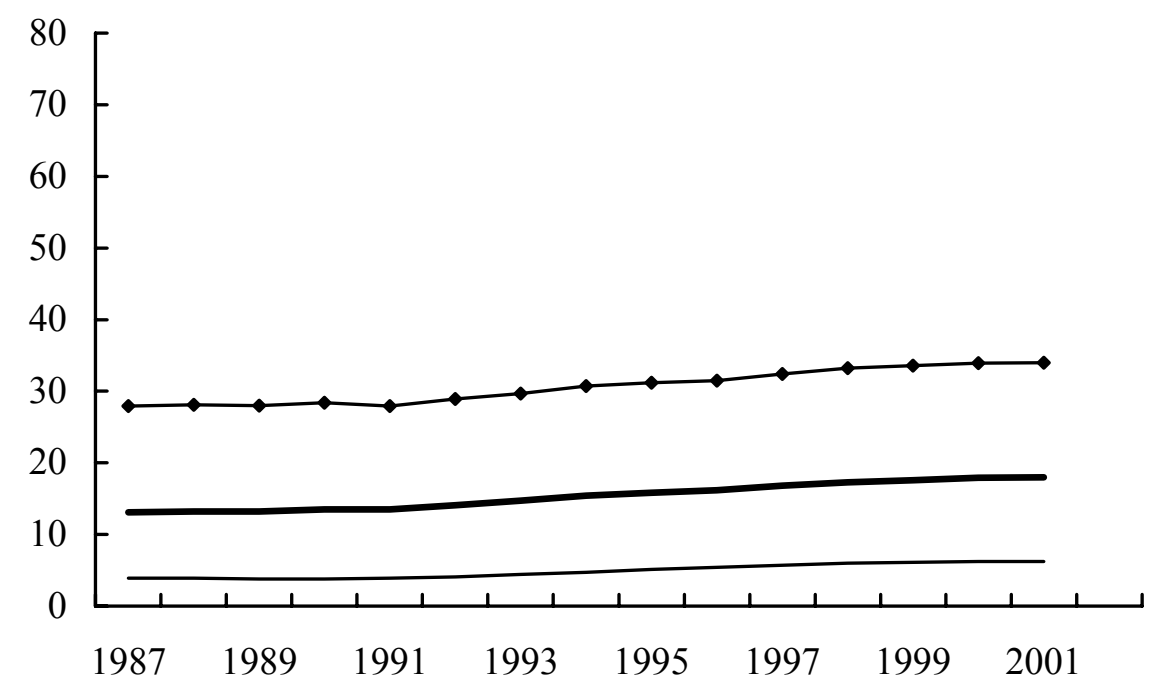

Fig 3.5 b Part time employment rate (\%) by gender in EU-15 countries in 2001
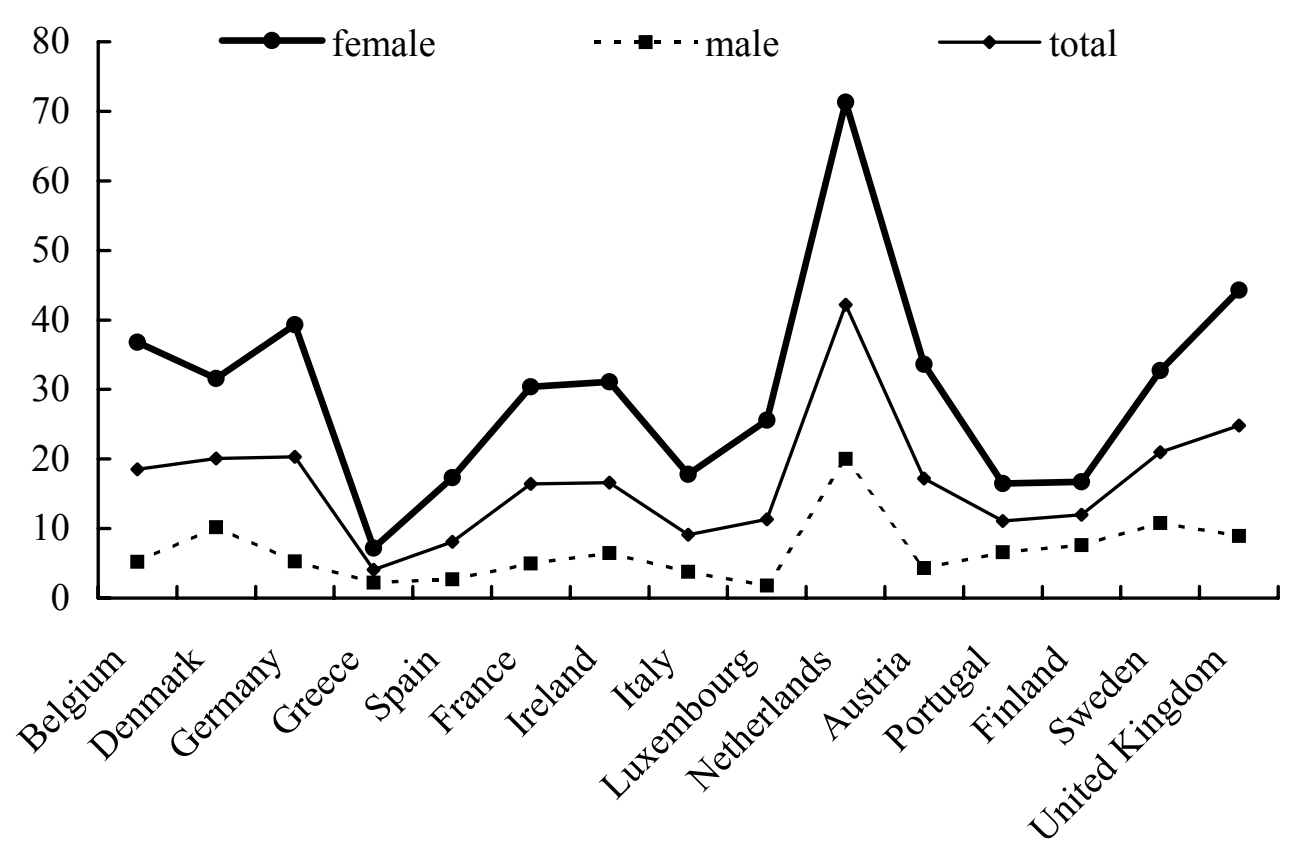
Fig 3.6 a Share of involuntary part-time employment - EU-15

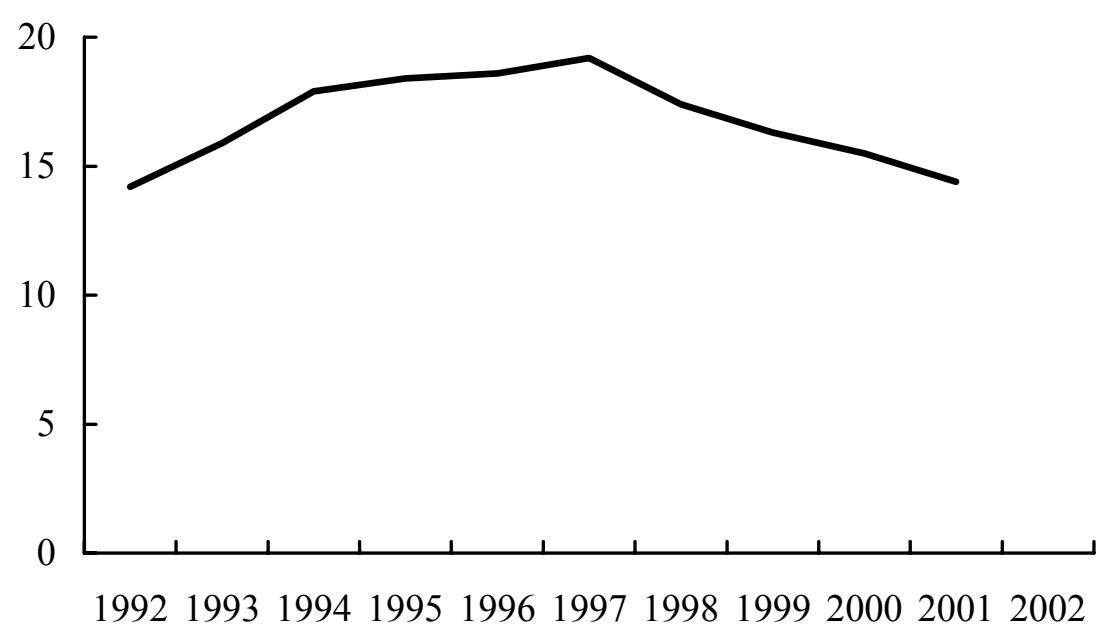

Fig 3.6 b Share of involuntary part-time employment - Relation with part-time employment rate

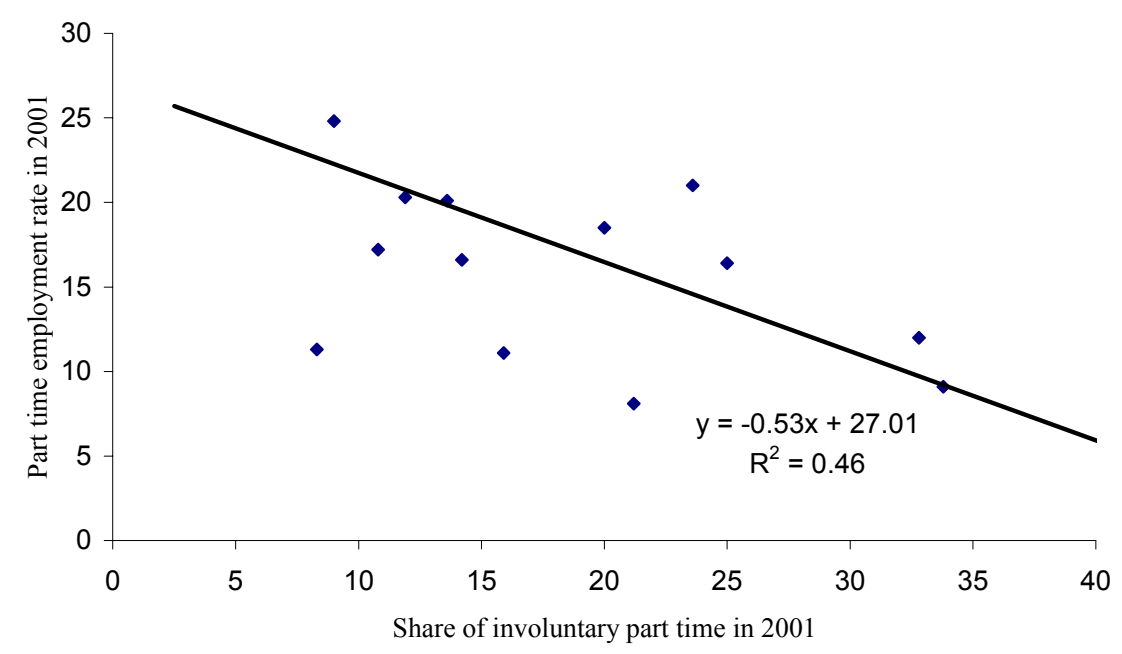

Source: Eurostat (Labour Force Surveys) 
Fig. 3.7 a Share of involuntary part-time by age group in the EU-15

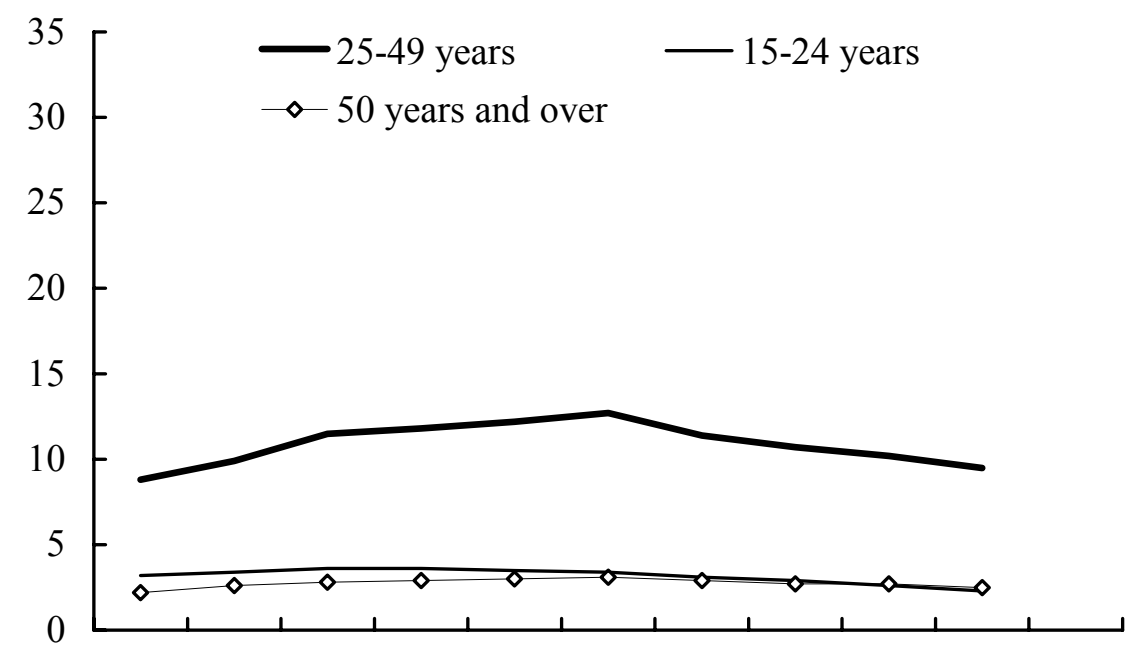

19921993199419951996199719981999200020012002

Source: Eurostat (Labour Force Surveys).

Fig. 3.7 b Share of involuntary part-time (\%) by age groups in EU-15 countries in 2001

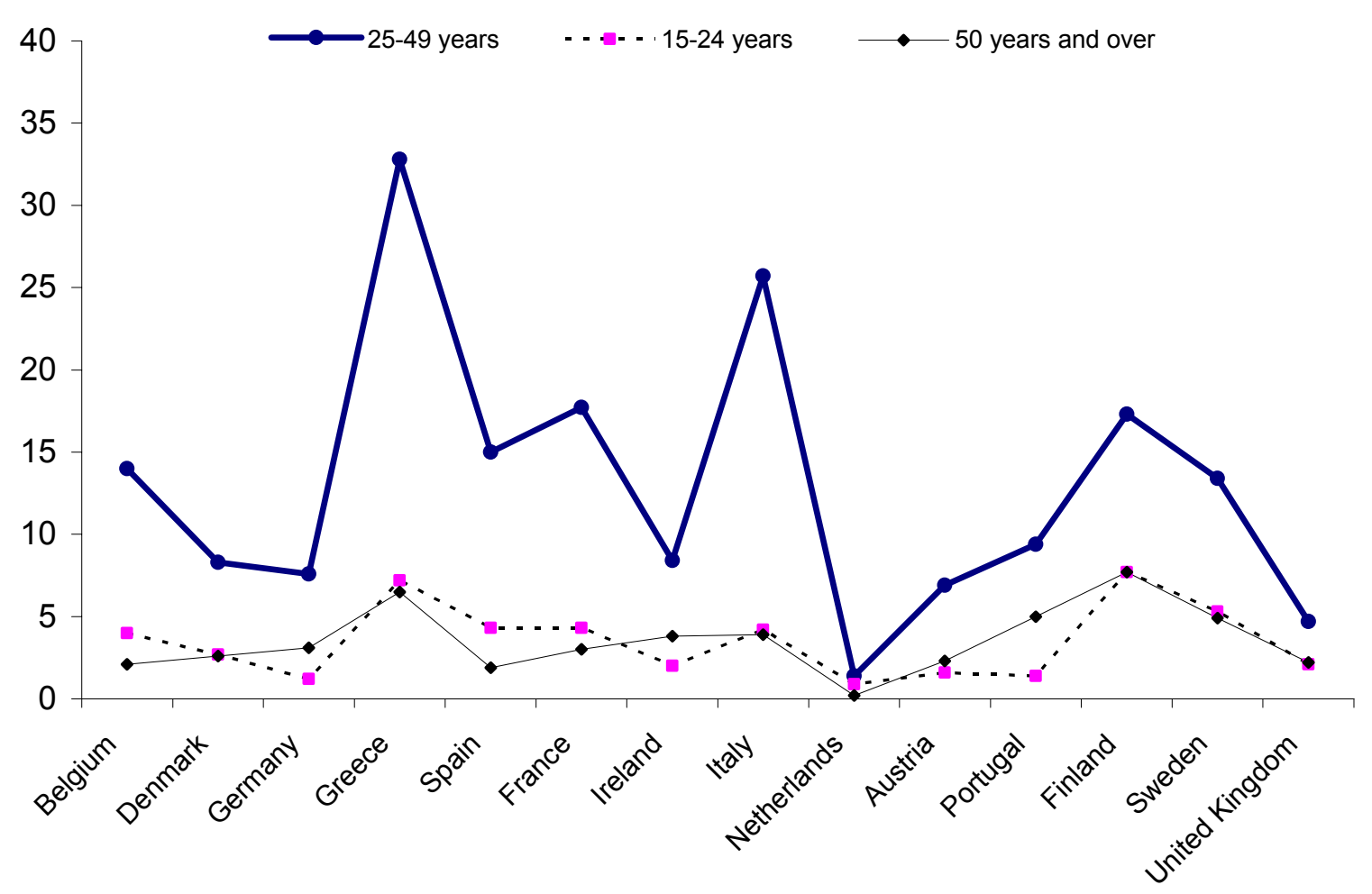


Figure 3.8 a Share of involuntary part-time by gender in the EU-15

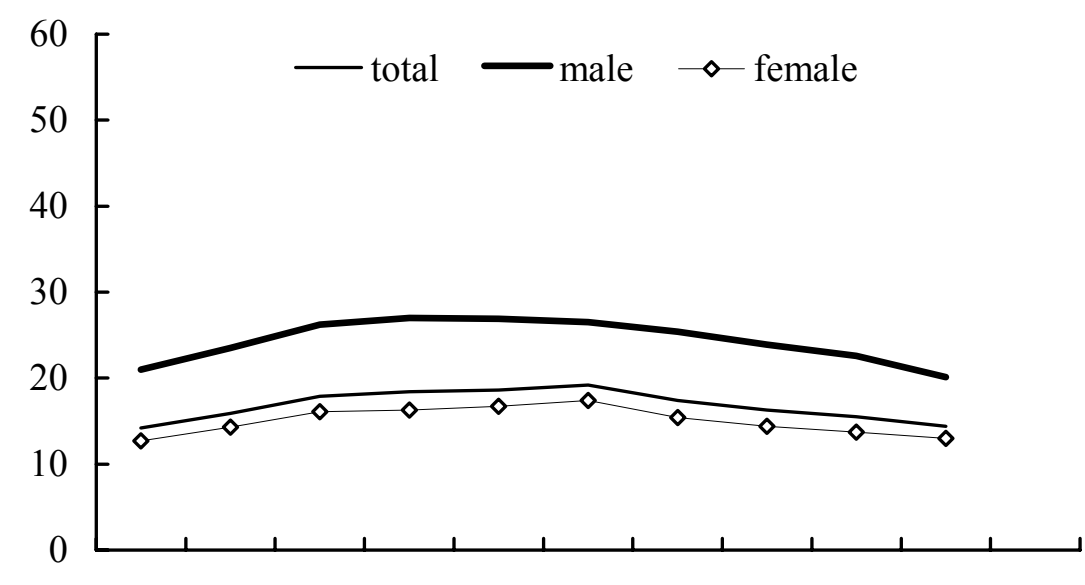

19921993199419951996199719981999200020012002

Source: Eurostat (Labour force surveys)

Fig. 3.8 b Share of involuntary part-time (\%) by gender in EU-15 countries in 2001

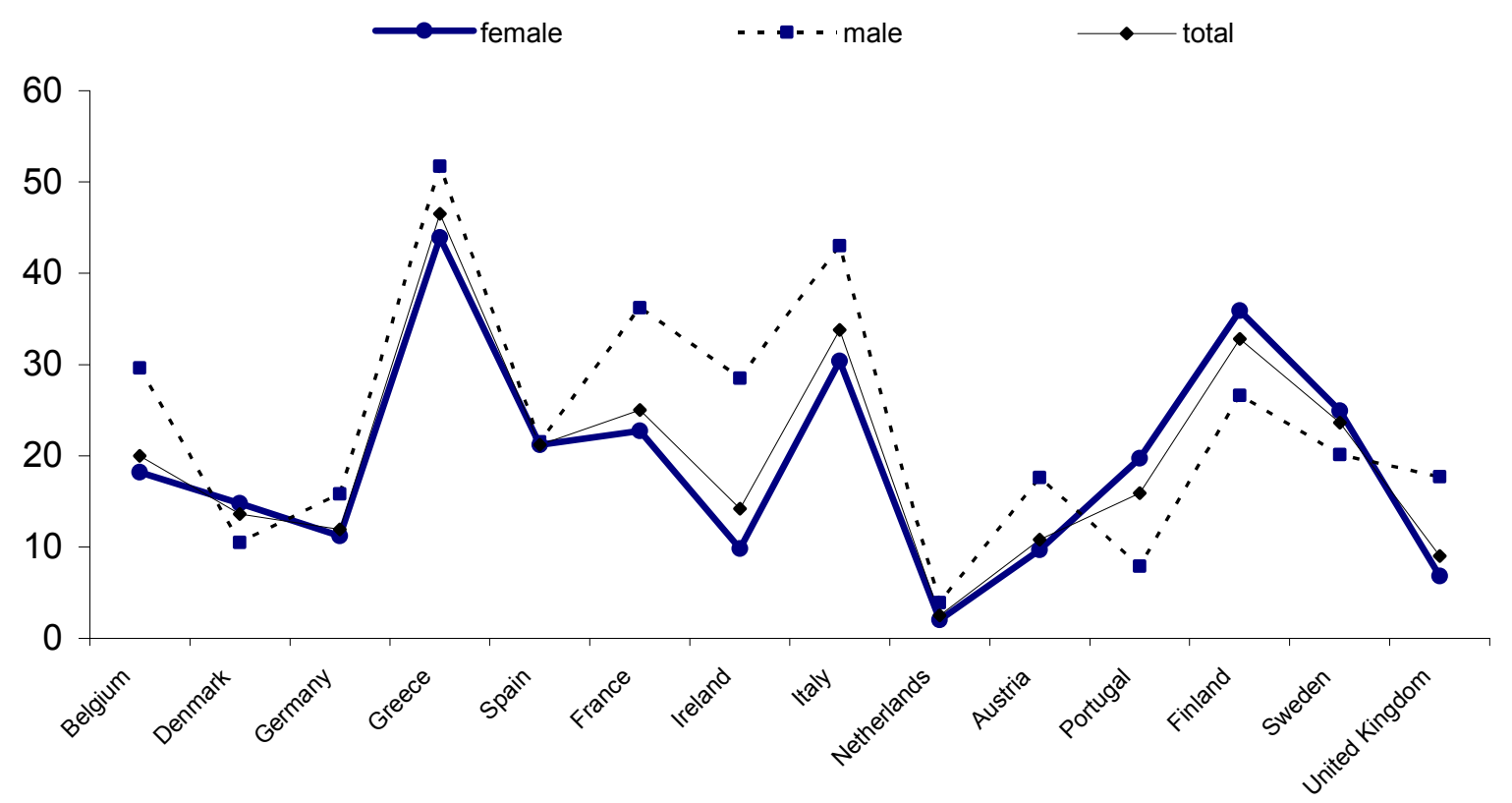




\section{Table 3.1}

(a) Part-time employment rate by occupation (\%)

\begin{tabular}{|c|c|c|c|c|c|c|c|c|c|c|}
\hline & Total & Legislators & $\begin{array}{l}\text { Pro- } \\
\text { fessionals }\end{array}$ & $\begin{array}{l}\text { Technicians } \\
\text { and } \\
\text { associate } \\
\text { professionals }\end{array}$ & Clerks & $\begin{array}{l}\text { Service } \\
\text { workers and } \\
\text { shop and } \\
\text { market sales } \\
\text { workers }\end{array}$ & $\begin{array}{l}\text { Skilled } \\
\text { agricultural } \\
\text { and fishery } \\
\text { workers }\end{array}$ & $\begin{array}{l}\text { Craft and } \\
\text { related } \\
\text { trades } \\
\text { workers }\end{array}$ & $\begin{array}{l}\text { Plant and } \\
\text { machine } \\
\text { operators } \\
\text { and } \\
\text { assemblers }\end{array}$ & $\begin{array}{l}\text { Elementary } \\
\text { occupations }\end{array}$ \\
\hline European Union (EU-15) & 18.0 & 6.8 & 14.8 & 17.3 & 24.3 & 34.2 & 16.4 & 3.9 & 6.0 & 34.0 \\
\hline Euro area & 16.3 & 6.6 & 14.6 & 16.8 & 24.3 & 27.7 & 16.5 & 4.0 & 5.3 & 32.9 \\
\hline BE Belgium & 18.5 & 5.9 & 20.6 & 12.6 & 21.8 & 39.1 & 12.5 & 4.4 & 5.5 & 32.0 \\
\hline DK Denmark & 20.1 & 4.8 & 11.7 & 19.6 & 22.4 & 42.0 & 6.6 & 2.0 & 3.0 & 38.0 \\
\hline DE Germany & 20.3 & 6.0 & 16.0 & 20.9 & 25.9 & 39.0 & 12.7 & 3.8 & 7.0 & 44.5 \\
\hline GR Greece & 4.1 & 1.1 & 4.1 & 2.7 & 28.5 & 4.7 & 7.4 & 2.1 & 1.0 & 11.6 \\
\hline ES Spain & 8.1 & 2.4 & 8.1 & 7.5 & 3.0 & 14.4 & 6.5 & 1.9 & 1.9 & 19.6 \\
\hline FR France & 16.4 & 5.9 & 12.8 & 14.5 & 7.3 & 32.2 & 15.4 & 4.4 & 4.6 & 37.1 \\
\hline IE Ireland & 16.6 & 6.8 & 12.5 & 12.8 & 23.7 & 37.9 & 20.0 & 3.9 & 6.3 & 31.7 \\
\hline IT Italy & 9.1 & 3.8 & 7.8 & 7.5 & 22.3 & 11.8 & 11.8 & 4.3 & 3.8 & 21.4 \\
\hline LU Luxemburg & 11.4 & 0.0 & 7.1 & 9.7 & 11.9 & 15.0 & 0.0 & 0.0 & 0.0 & 33.3 \\
\hline NL Netherlands & 42.2 & 19.4 & 38.1 & 43.9 & 12.9 & 70.0 & 40.9 & 11.8 & 22.8 & 68.5 \\
\hline AT Austria & 17.2 & 0.0 & 0.0 & 0.0 & 53.9 & 0.0 & 0.0 & 0.0 & 0.0 & 0.0 \\
\hline PT Portugal & 11.1 & 5.1 & 7.1 & 4.3 & 0.0 & 7.1 & 44.6 & 3.5 & 0.0 & 19.6 \\
\hline FI Finland & 12.0 & 3.7 & 9.4 & 9.7 & 3.4 & 27.3 & 16.2 & 3.3 & 5.2 & 26.5 \\
\hline SE Sweden & 21.0 & 6.1 & 14.9 & 14.8 & 12.9 & 44.1 & 24.1 & 6.8 & 8.2 & 39.4 \\
\hline UK United Kingdom & 24.8 & 7.4 & 16.1 & 20.7 & 25.8 & 55.9 & 14.2 & 3.4 & 9.1 & 36.9 \\
\hline
\end{tabular}


(b) Part-time employment rate by occupation (change between 1992 and 2001 in percentage points)

\begin{tabular}{|c|c|c|c|c|c|c|c|c|c|c|}
\hline & Total & Legislators & $\begin{array}{l}\text { Pro- } \\
\text { fessionals }\end{array}$ & $\begin{array}{l}\text { Technicians } \\
\text { and } \\
\text { associate } \\
\text { professionals }\end{array}$ & Clerks & $\begin{array}{l}\text { Service } \\
\text { workers and } \\
\text { shop and } \\
\text { market sales } \\
\text { workers }\end{array}$ & $\begin{array}{l}\text { Skilled } \\
\text { agricultural } \\
\text { and fishery } \\
\text { workers }\end{array}$ & $\begin{array}{l}\text { Craft and } \\
\text { related } \\
\text { trades } \\
\text { workers }\end{array}$ & $\begin{array}{l}\text { Plant and } \\
\text { machine } \\
\text { operators } \\
\text { and } \\
\text { assemblers }\end{array}$ & $\begin{array}{l}\text { Elementary } \\
\text { occupations }\end{array}$ \\
\hline European Union (EU-15) & 3.5 & -0.5 & 0.8 & 2.6 & 3.9 & 5.0 & 2.0 & -0.7 & -1.2 & 6.5 \\
\hline Euro area & 4.5 & 0.0 & 1.6 & 3.0 & 5.3 & 7.1 & 2.2 & -0.7 & -1.9 & 10.5 \\
\hline BE Belgium & 7.0 & 3.7 & 4.8 & 2.5 & 7.0 & 12.9 & 6.5 & 2.1 & 2.4 & 6.3 \\
\hline DK Denmark & -2.4 & -2.8 & -2.1 & -1.0 & -1.8 & -0.8 & -14.4 & 0.1 & -2.2 & -7.4 \\
\hline DE Germany & 6.0 & 1.1 & 2.7 & 6.4 & 5.6 & 9.6 & 4.2 & 0.8 & 1.9 & 20.8 \\
\hline GR Greece & -0.7 & -0.3 & 0.0 & -2.5 & -0.3 & -0.4 & -0.9 & -1.8 & -0.3 & 3.4 \\
\hline ES Spain & 2.3 & 0.3 & 0.9 & 1.2 & 3.6 & 7.2 & 0.1 & -0.5 & 0.3 & 5.2 \\
\hline FR France & 3.7 & -3.7 & 4.3 & 4.4 & 5.1 & 6.7 & 3.2 & 1.4 & 1.0 & 3.4 \\
\hline IE Ireland & 7.5 & 6.8 & 2.9 & 12.8 & 13.3 & 18.5 & 16.7 & 0.5 & 3.1 & 13.7 \\
\hline IT Italy & 3.2 & 3.8 & 4.0 & 3.2 & 6.5 & 5.6 & -0.5 & 1.1 & 1.5 & 7.1 \\
\hline LU Luxemburg & 4.6 & -6.7 & 0.5 & 4.1 & 4.6 & 10.1 & 0.0 & 0.0 & -22.2 & 7.0 \\
\hline NL Netherlands & 7.7 & 5.8 & 4.0 & 11.2 & 10.4 & 8.3 & 7.0 & 1.5 & 4.0 & 12.0 \\
\hline AT Austria & 17.2 & 0.0 & 0.0 & 0.0 & 0.0 & 0.0 & 0.0 & 0.0 & 0.0 & 0.0 \\
\hline PT Portugal & 3.8 & -5.4 & 0.4 & 0.8 & 0.8 & -4.0 & 28.8 & -1.0 & 0.0 & 6.5 \\
\hline FI Finland & 12.0 & 3.7 & 9.4 & 9.7 & 12.9 & 27.3 & 16.2 & 3.3 & 5.2 & 26.5 \\
\hline SE Sweden & 21.0 & 6.1 & 14.9 & 14.8 & 25.8 & 44.1 & 24.1 & 6.8 & 8.2 & 39.4 \\
\hline UK United Kingdom & 1.8 & -0.8 & -0.3 & 2.4 & 3.5 & 1.2 & 0.1 & -1.2 & 1.8 & -11.2 \\
\hline
\end{tabular}


(c) Part-time employment rate by sector, 2001 (\%)

\begin{tabular}{|c|c|c|c|c|c|c|c|c|c|c|c|c|c|c|c|c|c|}
\hline & EU-15 & $\begin{array}{l}\text { Euro } \\
\text { area }\end{array}$ & $\mathrm{BE}$ & DK & $\mathrm{DE}$ & GR & ES & FR & IE & IT & LU & NL & AT & PT & FI & SE & UK \\
\hline Agriculture & 17.4 & 17.0 & 12.8 & 16.1 & 17.0 & 7.6 & 7.3 & 14.9 & 11.4 & 14.8 & 7.8 & 36.8 & 17.8 & 42.2 & 15.6 & 35.6 & 18.1 \\
\hline Mining and quarrying & 3.0 & 2.9 & 8.6 & 0.0 & 2.4 & 0.0 & 0.6 & 3.4 & 4.8 & 4.8 & 0.0 & 9.2 & 5.9 & 0.3 & 3.7 & 0.0 & 3.8 \\
\hline Manufacturing & 7.6 & 7.5 & 5.6 & 7.8 & 10.4 & 1.6 & 2.9 & 5.6 & 6.3 & 5.2 & 2.7 & 23.1 & 8.1 & 3.0 & 4.2 & 9.0 & 7.9 \\
\hline Electricity & 5.5 & 5.5 & 7.0 & 0.0 & 5.2 & 0.0 & 2.1 & 9.0 & 5.5 & 3.6 & 10.6 & 17.5 & 4.0 & 0.0 & 2.4 & 3.5 & 6.2 \\
\hline Construction & 5.3 & 5.0 & 5.5 & 3.8 & 7.3 & 2.4 & 1.6 & 5.0 & 4.2 & 4.3 & 2.8 & 10.2 & 5.3 & 2.3 & 4.0 & 8.4 & 6.4 \\
\hline Industry & 6.8 & 6.7 & 5.6 & 6.6 & 9.5 & 1.8 & 2.4 & 5.6 & 5.5 & 5.0 & 3.0 & 19.0 & 7.2 & 2.7 & 4.1 & 8.6 & 7.3 \\
\hline $\begin{array}{l}\text { Wholesale and retail trade; } \\
\text { repair of motor vehicles }\end{array}$ & 23.1 & 19.5 & 22.0 & 24.7 & 28.9 & 3.2 & 8.1 & 16.9 & 26.6 & 10.1 & 10.8 & 44.7 & 24.3 & 8.0 & 20.6 & 23.4 & 38.6 \\
\hline Hotels and restaurants & 27.7 & 22.3 & 26.1 & 39.9 & 29.0 & 5.5 & 13.3 & 22.9 & 33.9 & 15.0 & 13.7 & 63.4 & 21.4 & 7.5 & 27.3 & 32.8 & 56.0 \\
\hline Transport & 10.9 & 10.0 & 7.8 & 15.3 & 13.1 & 1.2 & 3.7 & 10.0 & 9.1 & 4.6 & 6.5 & 30.6 & 9.9 & 2.5 & 9.9 & 16.9 & 13.0 \\
\hline Financial intermediation & 13.8 & 13.0 & 13.6 & 13.7 & 16.8 & 1.6 & 4.3 & 11.6 & 11.4 & 7.7 & 9.0 & 28.8 & 17.5 & 6.2 & 5.5 & 14.3 & 16.2 \\
\hline Real estate & 19.7 & 19.9 & 18.9 & 18.2 & 25.7 & 3.4 & 14.8 & 15.5 & 14.6 & 13.8 & 13.8 & 35.1 & 28.4 & 9.7 & 13.6 & 16.9 & 19.8 \\
\hline $\begin{array}{l}\text { Public administration and } \\
\text { defence; compulsory social } \\
\text { security }\end{array}$ & 13.6 & 12.8 & 20.4 & 11.7 & 15.1 & 0.9 & 2.9 & 17.5 & 8.4 & 7.3 & 9.1 & 26.9 & 11.6 & 1.8 & 5.8 & 13.7 & 18.0 \\
\hline Education & 25.9 & 22.6 & 29.5 & 22.6 & 34.3 & 7.9 & 14.4 & 20.4 & 21.6 & 10.1 & 20.5 & 55.6 & 16.5 & 7.0 & 12.3 & 24.6 & 38.2 \\
\hline Health and social work & 32.9 & 29.7 & 37. & 37.5 & 32.2 & 2.8 & 9.3 & 28.5 & 31.1 & 10.4 & 25.7 & 72.8 & 30.6 & 3.0 & 13.1 & 40.7 & 41.6 \\
\hline Other community & 27.3 & 25.2 & 23.9 & 28.5 & 29.5 & 5.5 & 14.6 & 26.6 & 29.5 & 14.6 & 21.0 & 54.6 & 25.0 & 10.5 & 20.7 & 32.6 & 34.4 \\
\hline $\begin{array}{l}\text { Private households with } \\
\text { employed persons }\end{array}$ & 59.4 & 59.0 & 73.5 & 64.8 & 81.4 & 30.3 & 51.4 & 66.3 & 53.2 & 47.8 & 55.0 & n.a. & 73.4 & 51.6 & 56.5 & n.a. & 64.3 \\
\hline $\begin{array}{l}\text { Extra-territorial } \\
\text { organizations and bodies }\end{array}$ & 6.9 & 6.9 & 5.9 & 0.0 & 5.4 & n.a. & 9.1 & 9.9 & 18.6 & 8.4 & 4.0 & n.a. & 3.8 & 10.6 & n.a. & n.a. & 7.1 \\
\hline Services & 22.7 & 20.5 & 23.1 & 25.1 & 26.0 & 4.1 & 11.3 & 20.5 & 22.1 & 10.7 & 13.7 & 47.5 & 21.7 & 8.8 & 14.8 & 26.4 & 30.9 \\
\hline Total & 18.0 & 16.2 & 18.5 & 20.1 & 20.3 & 4.1 & 8.2 & 16.4 & 16.5 & 9.1 & 11.3 & 41.0 & 17.2 & 11.1 & 11.9 & 22.3 & 24.8 \\
\hline
\end{tabular}

Sources: Eurostat (Labour Force Surveys). 
Table 4.1 Main regulatory measures impacting on working time adopted until 2001

\section{Country Measure}

Belgium Voluntary reductions in individual working time

Interruption de carrière à temps partiel (part-time career; break since 1996): a full-time worker reduces his working time by between 80 and $50 \%$ being replaced by a previously unemployed person.

Part-time working

Plans d'entreprises de redistribution du travail (enterprise plans to redistribute employment; since 1994): firms create new jobs to compensate for reductions in individual working hours.

Accords pour l'emploi (employment agreements): firms introduce part-time working on a voluntary basis together with another measure designed to encourage hiring.

Promotion de la remise au travail de chômeurs à l'aide de la redistribution du travail (promotion of vocational reintegration for the unemployed through the redistribution of employment) workers who opt for part-time work receive an incentive (Flemish region only; up to end 1995).

Germany Gesetz über Teilzeitarbeit und befristete Arbeitsverträge (act on part-time work): right for employees in firms with more than 15 employees to reduce their working time as long as no internal company reasons prevent such a reduction (since 1 January 2001).

Spain The definition of part-time work was amended. Article 12.1 of None the 1980 Workers' Statute laid down that a part-time worker was one who worked less than $2 / 3$ of normal contractual hours. The 1994 reform removed this threshold, so that part-timers are now defined as those who work any number of hours less than the normal contract. In addition, it permits the calculation of hours on an annual basis.

\section{Incentives to employees}

Monthly, flat-rate benefit between $59.82 €$ and $149.55 €$ depending on the size of the reduction.

None

None

$74.37 €$ to $123.95 €$ per month for two years maximum depending on the extent of hours reduction.

\section{Incentives to employers}

Temporary reduction reduction in social security contributions for hiring unemployed person.

Reduction of social security contributions by a maximum of $929.60 €$ per extra employee, for 13 quarters.

Reduction of social security contributions by $929.60 €$ per quarter per extra employee, for duration of agreement.

Unemployed workers receiving full benefits may be hired to make up lost hours.

None

Reduction in social security contribution. 
Spain

(continued)

In 1998 the Spanish government and labour trade unions signed an agreement on part-time employment contracts which seeks to improve the conditions of part-time workers.

The 2001 decree on labour market reforms increased further the flexibility of part-time jobs: the decree allows working hours additional to the agreed part-time hours to be distributed over the year, with 7 days' notice given to the worker.

France

Abattement de cotisations sociales patronales pour les emplois à temps partiel (reduction of employers' social security contributions for part-time employment; since 1992): employers transform positions from full-time to part-time or hire part-time workers (with hours between 16 and 32). The volume of employment in hours must be maintained. This rebate of social security contributions for part-time employment was abolished in 2000, following the implementation of the collective working time reduction (35 hours working week).

A 2000 legislative decree set out new regulations on part-time work towards more flexibility. Part-time work may be 'horizontal' (where the hours are reduced on a daily basis) or 'vertical' (where the work is executed full-time, but only in certain fixed periods during the week, month or year). Collective bargaining may permit the combination of vertical and horizontal part-time work. The decree repeals the law which allowed collective bargaining to set limits on the proportion of part-time workers in the full-time workforce. The decree lifts the ban on extra hours (paid at the same rate as ordinary hours below a ceiling) and overtime for part-timers (in the case of vertical part-time work) and introduces the possibility of making the distribution of work laid down in the individual employment contract flexible. In the case of parttime vacancies, employees already working full-time may ask to change their employment relationship into a part-time arrangement.

The reform provides employees with social security None

benefits pro-rata to the number of hours worked.

None

None discrimination' between part-time and full-time workers (no difference as regards trade union rights, pays, annual holidays, parental leaves, protection against workplace accidents and occupational illness and access to company training schemes)
Reduce the risk of overtime payment.

The reduction of social security contributions was $30 \%$ as of April 1994, for jobs with duration between 16 and 32 hours. Since late 1995, it could be combined with the abatement for low-paid workers.

A total of 310 million euros has been allocated to finance over 3 years relief on the social security contributions paid by employers in respect of part-time permanent recruitments which, in the course of 2000 , give rise to an increase in employment. 

redistributing existing employment more effectively, that is, an approach which encompasses several methods of redistributing employment, such as working time reduction, part-time work. This led to a strong increase in part-time jobs in firms in the 1980 s and the early 1990s, especially for women.

The general principle of equal treatment, regardless of working time, was introduced in Labour Law in November 1996.

Part-time employees can claim the same rights as full- None time workers.

Austria Solidaritätsprämienmodell (voluntary reductions in individual working time): from 1998, collective or work agreements may permit reduction of normal working hours in order to recruit registered unemployed persons. Reductions have to be agreed between the employer and each employee.

From 1998, employees over 50 with family care responsibilities may reduce working time while maintaining employment rights, subject to employer's agreement. This must be given if there are more than 10 employees and the employee is entitled to a part-time pension (Gleitpension)

Finland Part-time supplement (since 1994): employees reduce their working-time by $40 \%$ to $60 \%$ with the agreement of the employer for 1 year. An unemployed person must be recruited to the same position.

Employees working less than normal hours receive a None proportion of unemployment benefit; employmen rights are maintained.

Source: OECD Employment Outlook (1998), EIRO website, national sources. 
Table 5.1 Determinants of part-time employment rates

Dependent variable:

Part-time employment rate (\%)

(1) (2)

(3)

(4)

(5)

(6)

(7)

Change in part-time regulation

(more favourable) excluding the

Netherlands

$0.165 \quad 0.165$

$(2.10)^{* *} \quad(2.32)^{* *}$

0.131

0.125

0.375

029

Change in part-time regulation (more

favourable) including the Netherlands

Children benefits (\%)

$-1.437$

$\begin{array}{cc} & 0.349 \\ & (6.26)^{* * *} \\ -1.679 & -1.045\end{array}$

$(1.81)^{*}$

$(1.94)^{*}$

$(6.74)^{* * *}$

$(0.25)$

EPL

0.622

$(-4.53)^{* * *}$

-1.045
$(-3.10) * * *$

-2.01
$(-5.19)$

$-1.551$

$(-4.52)^{* * *}$

$-0.881$

$-2.999$

$(1.73)^{*}$

EPL for regular jobs

EPL for temporary jobs

Unemployment benefit replacement

ratios (\%)

Unemployment benefit duration

$\begin{array}{ccc} & 2.512 & 2.207 \\ & (5.44)^{* * *} & (4.65)^{* * *} \\ & 0.072 & -0.126 \\ & (0.42) & (-0.93) \\ -0.0145 & -0.0188 & -0.0103 \\ (-1.39) & (-2.09)^{* *} & (-1.25) \\ -1.090 & -0.790 & 0.099 \\ (-0.99) & (-0.80) & (0.12)\end{array}$

Total labour tax rate

$\begin{array}{llll}2.732 & 2.004 & 1.961 & 4.600 \\ (6.9)^{* * *} & (5.02)^{* * *} & (3.51)^{* * *} & (3.65)^{* * *} \\ 0.069 & 0.171 & -0.337 & -0.684 \\ (0.41) & (1.12) & (-2.25)^{* *} & (-1.51) \\ -3.571 & -0.0164 & -0.026 & -0.0363 \\ (-2.79)^{* *} & (--2.13)^{* *} & (-2.62)^{* * *} & (-1.63) \\ -1.488 & -1.431 & -0.087 & 5.340 \\ (-1.44) & (-1.69)^{*} & (-0.09) & (1.67)^{*} \\ 10.42 & & & \\ (2.07)^{* *} & & & \end{array}$

Controls (\%)

Female participation rate

$\begin{array}{lll}0.381 & 0.401 & 0.354 \\ (10.30)^{* * *} & (12.14)^{* * *} & (12.25)^{* * *} \\ -0.071 & -0.075 & -0.075 \\ (-1.53) & (-1.73)^{*} & (-1.93)^{*} \\ 4.886 & 4.424 & 2.313 \\ (5.35)^{* * *} & (5.45)^{* * *} & (3.29)^{* * *} \\ 0.033 & 0.079 & 0.082 \\ (1.34) & (3.41)^{* * *} & (3.79)^{* * *}\end{array}$

$(2.07)^{*}$

Output gap

Fertility rate

Schooling rate of $15-25$ population

(1.34)

$(3.41)^{* * *}$

$\begin{array}{lc}0.082 & 0.0574 \\ (3.79)^{* * *} & (2.51)^{* *}\end{array}$

Share of temporary jobs

Share of employment in services

Constant

-13.637
$(-2.45)^{* *}$

0.393

$0.393 \quad 0.317$

0.317
$(9.43)^{* * *}$

0.271

$-0.084$

$(-2.05)^{* *}$

$-0.025$

$(7.84)^{* * *}$

0.327

$\begin{array}{ll}-0.075 & -0.084 \\ (-1.93)^{*} & (-2.05)^{* *}\end{array}$

-0.025
$(-0.65)$

$(5.18)^{* * *}$

$\begin{array}{ll}4.791 & 8.230 \\ (5.73)^{* * *} & (6.96)\end{array}$

$(-2.74)^{* * *}$

$-0.350$

8.230
$(6.96) * * *$

$(-2.52)^{* *}$

$(2.86)^{* * *}$

0.051
$(2.32)^{* *}$

0.010

$(2.86)$

$(2.32)^{* *}$
0.0728

$(0.45)$

0.169

(2.52)** $\quad(1.19)-0.0156$

$\begin{array}{lll}(2.52)^{* *} & (1.19) & (2.17)^{*} \\ 0.229 & 0.0777 & 0.302\end{array}$

$\begin{array}{lll}0.229)^{* * *} & (1.18) & (1.67)^{*}\end{array}$

Observations

Number of countries

172

$-14.382$ $(-3.24)^{* * *}$ -11.933
$(-2.75)^{* * *}$

$(1.18)$ $(-7.31)^{* * *}$

$(-0.78)$

$-43.724$

14

$(-8.22)^{* * *}$

154

14

14

yes yes

Instrumented variables

no yes

no ye

14

154 $(-4.04)^{*}$

no

yes
no

yes

no

14

yes

yes 
Sources: Eurostat, Labour force surveys, OECD economic outlook, OECD labour market database, Nickell, Nunziata and Ochel (2002), Nickell and Nunziata database.

${ }^{(1)}$ Countries included all the European Union member states except Luxembourg and Greece (Belgium, Denmark, Germany, Spain, France, Ireland, Italy, Netherlands, Austria, Portugal, Finland, Sweden and the UK). To increase the cross-section dimension, we have also added Norway in the regression, for which data available however display a very poor time series dimension.

Absolute value of t- statistics in parentheses. * significant at $10 \% ; * *$ significant at $5 \% ; * * *$ significant at $1 \%$.

Note: The equations are generally estimated by generalised least squares allowing for heteroskedastic errors and common-across-group first order serial correlation. Each equation contains country dummies, intercepts and specific dummy for 1990-91 to take into account the German reunification. When indicated, the two-stage least squares within estimator (fixed-effects regression estimator with instrumental variables) has also been used as a method to correct for possible endogeneity. The instruments are the variables lagged by two years. The panel is unbalanced as part-time employment series are starting later for some countries (Austria, Finland, Norway and Sweden). 